Fall 2014

\title{
Sacred Cows, Holy Wars: Exploring the Limits of Law in the Regulation of Raw Milk and Kosher Meat
}

Kenneth Lasson

University of Baltimore School of Law, klasson@ubalt.edu

Follow this and additional works at: http://scholarworks.law.ubalt.edu/all_fac

Part of the Constitutional Law Commons, Consumer Protection Law Commons, First Amendment Commons, and the Religion Law Commons

\section{Recommended Citation}

Sacred Cows, Holy Wars: Exploring the Limits of Law in the Regulation of Raw Milk and Kosher Meat, 13 DePaul Bus. \& Comm. L.J. $1(2014)$

This Article is brought to you for free and open access by the Faculty Scholarship at ScholarWorks@University of Baltimore School of Law. It has been accepted for inclusion in All Faculty Scholarship by an authorized administrator of ScholarWorks@University of Baltimore School of Law. For more information, please contact snolan@ubalt.edu. 


\title{
Sacred Cows, Holy Wars: \\ Exploring the Limits of Law in the Regulation of Raw Milk and Kosher Meat
}

\author{
Kenneth Lasson*
}

\section{CONTENTS}

I. IntROdUCtION ................................ 1

II. Milk and Meat Together: The Historical BACKDROP.................................. 3

A. Religious Injunctions ....................... 3

B. From Community Regulation to Big Business ....... 12

C. Governmental Intervention and Involvement ........ 16

III. SACred Cows: Legal Controversies over

Regulating Meat and Milk ................... 25

A. Statutory Regulation of Kosher Fraud ............. 29

B. Kashrutand the Courts ....................... 33

C. The Raw Milk Controversy ................... 42

IV. Holy Wars: Law, Politics, and Filthy Lucre..... 44

A. "Something Ain't Kosher Here." ................ 44

B. Kosher Certification Agencies .................. 47

C. Law and Politics in the Business of Kashrut ....... 51

V. Summary and Conclusion ....................... 65

\section{INTRODUCTION}

Murder and mayhem may dominate the headlines, but nothing lingers in the public consciousness with more passion and constancy than religious quarrels. When rules and taboos are broken, communities are roiled and individuals skewered. No less controversial is when scientific discoveries and technological advances are put forward to explain and change the laws, or when the government seeks to regulate or control their conflicting effects on consumer fairness - or where the primary goal is the enhancement of corporate profits.

This last factor is increasingly the case nowadays in the relatively small but rapidly growing world of kosher food, where religious rul-

* Professor of Law, University of Baltimore. I am greatly indebted to my research assistants on this project: Sean Dobbs, Justin Schnitzer, Yosef Kuperman, and Jessica Swadow. 
ings both picayune and profound often lead to arguments and scandals that camouflage the basic question: Is it kosher or is it not?

Law and religion seldom coincide comfortably in a free society, tending instead to reflect the inherent tension that resides between the two. This is nowhere more apparent than in America, where the first freedom ennobled by the Bill of Rights - religious liberty - and the underlying principle upon which it is based - the separation of church and state - are conceptually at odds, especially in view of the compromises that must sometimes be made. Although we always cling to the fundamental importance of individual rights and civil liberties - that any activity must be permitted if it is not imposed upon others without their consent, and does not adversely affect them - we are also fundamentally "a religious people whose institutions presuppose a Supreme Being."1

The accommodations that ensue from these competing values have generally been borne in good faith if not a spirited civility that, arguably, defines our way of life. The national psyche is to appreciate the nobility of a tolerant and multi-cultural society, as well as the necessity for promoting law and order by promulgating rules and regulations.

To be sure there are not always easy solutions for the common good. At times governmental controls cause more problems than they resolve. The current and provocative issues surrounding the regulation of raw milk and the supervision of kosher meat are good examples. Both reach impasses that are quite understandable if not completely predictable because, ultimately, religion and law reach into every stage of food preparation and delivery, from pasture to market. In the United States, the government takes pains to ensure that the supply of meat and milk is safe and plentiful. ${ }^{2}$ In the process, it has outlawed milk that has not been pasteurized ${ }^{3}$ and prosecuted sellers of "kosher" or "halal" meat that does not fully adhere to traditional Jewish or Islamic standards. ${ }^{4}$ While the law does not take sides,

1. Zorach v. Clauson, 343 U.S. 306, 313 (1952). American notions of civil liberties are often traced to John Stuart Mill, whose famous essay On Liberty rests upon two assumptions: (1) that all restraint is an evil and that leaving people to themselves is always better than controlling them, and (2) that the sole end for which mankind may interfere with the liberty of others is for self-protection or to prevent harm to others. See JoHn STUART Mill, ON LiberTy 9 (Elizabeth Rapaport ed., Hackett Publishing Company, Inc. 1978) (1859). "[S]o natural to mankind is intolerance . . that religious freedom has hardly anywhere been practically realized." Id. at 8 .

2. See, e.g., FDA, U.S. Dep't of Health and Human Servs., Food Code (2013), available at http://www.fda.gov/downloads/Food/GuidanceRegulation/RetailFoodProtection/FoodCode/U CM374510.pdf [hereinafter Food CODE].

3. See Id. at 59.

4. See infra Part III.A. 
it occasionally runs afoul of Constitutional principles separating church and state: various courts have thus ruled that kosher butchers implicitly stipulate their compliance with rabbinic authorities, that a state law may incorporate a rabbinical ruling on kosher labeling; and that kosher symbols may be subject to trademark infringement laws.

That all religions have their sacred cows and holy wars neither demeans nor necessarily sanctifies them. This article tells some of the intriguing stories that happen when private and public regulatory schemes come to create difficulties in protecting both the consuming public and individual rights. Part II presents a colorful historical backdrop regarding kashrut. Part III describe early civil and criminal litigation. Part IV catalogues the burgeoning roster of competing supervisory agents and organizations. Part $\mathrm{V}$ gives an inside look at the more compelling cases that have arisen in recent years. Part VI provides a summary and conclusion.

What emerges is a tale of religion, politics, and filthy lucre ${ }^{5}$ that goes far beyond your father's first food fight: not only a fascinating picture of how contemporary life and mores have evolved, but as well a sobering (and often entertaining) example of the limitations of the law.

\section{Milk and Meat Together: The Historical Backdrop}

Thou shalt not seethe a kid in his mother's milk. - Exodus 23:19

Before embarking on this somewhat bumpy, colorful, and provocative journey through the business of keeping kosher, it's helpful to know something about the traditions that are supposed to be the purpose of the "dietary laws."

\section{A. Religious Injunctions}

According to at least some Biblical scholars, mankind was originally meant to be vegetarian, prohibited from killing animals and eating

5. "Filthy lucre" originally connoted money obtained dishonestly. See Filthy Lucre, Dicrion. ARY.COM, http://dictionary.reference.com/browse/filfthy+lucre (last visited Nov. 22, 2014). For example, "She didn't like the job but loved the filthy lucre in the form of her weekly paycheck." Id. The term entered the language in King James Bible: "Not given to wine, no striker, not greedy of filthy lucre; but patient, not a brawler, not covetous." 1 Timothy 3:3 (King James). "Whose mouths must be stopped, who subvert whole houses, teaching things which they ought not, for filthy lucre's sake." Titus 1:11 (King James). 
them. ${ }^{6}$ That restriction was relaxed following the Great Flood of Noah's time, after which it was permitted to use meat for food. ${ }^{7}$

The word "kosher" - which to both Jews and others is a synonym for correct, genuine, clean, or legitimate - has long been part of the English vernacular. ${ }^{8}$ It derived originally from the Hebrew noun $\mathrm{ka}$ sher,${ }^{9}$ meaning "fit" or "proper," 10 but today refers primarily to the set of Jewish dietary laws which dictate strict standards concerning both what is permissible to eat and how all food must be prepared. ${ }^{11}$ The basic rules are found in the Torah, ${ }^{12}$ and have evolved through rabbinic interpretation and elaboration over the past fifteen hundred years.

The precepts of kashrut (food that can or cannot be consumed under Jewish law) are first mentioned in the Book of Exodus. ${ }^{13}$ They can be classified into four categories: (1) animals that are permitted and forbidden; (2) conditions that render ordinarily permitted animals

6. See Chanan Morrison, Gold From the Land of Israel 31 (2006); Genesis 1:29-30 (King James).

7. See Genesis 9:2-3; Leviticus 11:3; Deuteronomy 14:6 (King James). According to at least one prominent Jewish theologian's interpretation, pre-deluvian man craved meat and had no compunctions about killing either humans or animals to get it. See Morrison, supra note 7, at 31-32. Rabbi Kook predicts that in the future, as we approach Messianic times, Mankind's inner goodness will reassert itself and once again we will not eat meat. See id. at 32.

8. Commack Self-Service Kosher Meats, Inc. v. Weiss, 294 F.3d 415, 418 (2d Cir. 2002).

9. Id.

10. See Oxford Dictionary of the Jewish Religion 419 (2d ed., 2011) (defining "kasher").

11. Id. Contrary to what has become something of a popular notion in secular culture, "kosher" does not mean blessed by a rabbi, but refers to anything that is fit for use or correct according to halacha (Jewish law). Id. Various related terms will be used throughout this article. Food that is not in accordance with Jewish law is called treif, which derived from terefah. Id. at 732. The kosher slaughtering process is called shechita, the slaughterer is a shochet (plural shochtim). Id. at 672 (defining "ritual slaughter"). Kosher animals maybe rendered unfit for consumption based on two distinct principles: treif and neveilah. Neveilah refers to any kosher mammal or fowl killed in a method other than the ritually prescribed method of slaughter (shechita). Binyomin Forst, The Laws of Kashrus 36 (Nosson Scherman \& Meir Zlotowitz ed. 1993). By contrast, an animal maybe a kosher animal, ritually slaughtered, and still be found treif, or non-kosher. Id. at 37-38. Treif refers to any animal with a mortal injury. Id. Injuries not recognized as fatal by the Bible, even if thought to be mortal injuries by modern medicine, will not render an animal treif. Id. at 37. Generally the eight categories of treifos are injuries to: (1) the brain and spine; (2) the jaw bone and food pipes; (3) air pipes and lungs, with their organs; (4) heart; (5) liver and gall, milt, kidney and bladder; (7) intestines, and four stomachs; and (8) limbs and ribs. See OXFORD, supra note 11, at 732-33 (2d. 2011) (defining "terefah"). "Kosher" has also insinuated itself into American slang, meaning "acceptable" or "cricket" such as "Is it kosher to do this?" or "Do you want me to kosher it with the boss for you?" It also has to do with alcohol that is not diluted, as in "I'll take mine kosher with a little ice." RICHARD Spears, american Slang Dictionary 209 (4th ed. 2006).

12. Deuteronomy 12:21 \& 14:12-21; Exodus 22:31; Leviticus 11:3-31 \& 17:10 (King James).

13. Exodus $22: 30 \& 23: 19$ (King James). 
unfit; (3) prohibited mixtures; and (4) instances when the laws can be superseded by other considerations (nullification). ${ }^{14}$

Scripture provides that to be considered kosher mammals have split hooves and chew their cud, ${ }^{15}$ and that fish have both fins and scales. ${ }^{16}$ All pork and shellfish products are categorically forbidden. ${ }^{17}$ Twentyfour species of birds are prohibited; ${ }^{18}$ all others are permitted. Similarly, the Old Testament categorically bans the consumption of virtually all insects and rodents, with the solitary exception of four species of grasshopper. ${ }^{19}$

Oral tradition further enumerates the features of non-kosher animals and birds, such as the parts of otherwise kosher creatures that are regarded as unfit. ${ }^{20}$ For example, the Bible prohibits the eating of the sciatic nerve. ${ }^{21}$ But removing the nerve is a difficult process, so that many Jewish communities have adopted the practice of not eating any part of the hindquarters. ${ }^{22}$ Similarly forbidden, under the penalty of excommunication, is the consumption of blood and certain organs from either fowl or mammal. ${ }^{23}$

Also prohibited is the combination of certain food types that may otherwise be kosher - such as eating meat and milk products at the same meal. ${ }^{24}$ The literal prohibition - "Thou shall not seethe a kid in its mother's milk" - appears three times in the Bible. ${ }^{25}$ According to tradition, the verse is to be read generally, not literally: one may not cook any meat and milk items together. ${ }^{26}$ Moreover, each verse describes a different prohibition about cooking, eating, and deriving benefit from the mixture. ${ }^{27}$

14. See e.g. Deuteronomy 14; Exodus 23 (King James).

15. Leviticus 11:1-3 (King James).

16. $I d$. at $11: 9$.

17. Id. at $11: 7 ; 11: 9-12$.

18. See, e.g., id at 11:13-19.

19. See id. at 11:20-23.

20. Genesis 32:32 (King James).

21. Id.

22. See Ari Z. Zivotofsky, What's the Truth about . . Nikkur Achoraim?, Jewish Action (Winter 2009), available at http://oukosher.org/blog/consumer-kosher/whats-the-truth-about-nik kur-achoraim/ (explaining the background and sources underlying the customs of Nikkur Achoraim; not eating from animal's hindquarters.).

23. Genesis 32:32. See also, Zivotofsky, supra note 23; Krisos, in The Babylonian Talmud 98 (I. Epstein ed., Samual Daiches \& Israel Slotki trans., Socino Press London 1960), available at http://www.halakhah.com/rst/kodoshim/47\%20-\%20Krisos.pdf.

24. See Exodus 23:19 (King James).

25. Id.

26. See, e.g., Is it Kosher? Some General Laws of Kashrus, KosherQuest, http://www.kosher quest.org/book.php?id=SOME_GENERAL_LAWS_OF_KASHRUS.htm (last visited Nov. 24, 2014) [hereinafter KosHeRQuest].

27. Exodus 23:19 \& 34:26; Deuteronomy 14:21 (King James). 
Forbidden mixtures may be nullified - that is, made fit to be eaten together - by way of rabbinic rules. ${ }^{28}$ If the dairy ingredient is found only incidentally, for example in barely traceable amounts, it may be consumed without violating the general prohibition. ${ }^{29}$

The dietary laws concerning fish is a different matter altogether. As noted earlier, certain seafood is absolutely forbidden, while others are not. ${ }^{30}$ But the rules get considerably more complicated when dealing with insects. According to the Talmud, eating fish whose stomachs contain insects or worms is prohibited, but not those found in the flesh. ${ }^{31}$ Recent studies by marine biologists, however, suggest that the larger fish swallowed a smaller fish that initially swallowed the insect, and, thus, the insects subsequently penetrated the flesh of the larger fish. ${ }^{32}$ This analysis has generated considerable debate among modern rabbis - some holding that, because the source of the insects cannot be determined, all such fish should be avoided, others arguing that current scientific evidence cannot be accepted if it conflicts with Talmudic teachings. ${ }^{33}$

Rabbi Moshe Feinstein, however, perhaps the leading decisor of the Twentieth Century, took a more lenient position, reasoning that insects found in the flesh of fish are very small and are often not noticeable to the naked eye; thus, they would still not be considered prohibited until they exit the fish into the ocean. ${ }^{34}$

The Orthodox Union asked a parasitologist at the American Museum of National History to determine if worms found in sample cans of sardines come from the intestinal tracts of the fish or from worms

28. Forst, supra note 12, at 52-61 (Nosson Scherman \& Meir Zlotowitz ed. 1993).

29. Id. Rov, or simple majority, is applicable when there is a problem of identification. $I d$. at 53. For example, when one piece of non-kosher meat is placed between two pieces of kosher meat, it is considered to be kosher. See id. By contrast, when there is a transfer of flavor, the mixture is not permitted until the taste is undetectable; this is generally achieved by nullification by a $60: 1$ ratio. Id. at $52,57-61$.

30. Leviticus 11:7; 11:9-12 (King James).

31. Chullin, in The Babylonian Talmud 20 (I. Epstein ed., Samual Daiches \& Israel Slotki trans., Socino Press London 1960), available at http://www.halakhah.com/rst/kodoshim/43c\%20. \%20Chullin\%20-\%2061a-89a.pdf. See also Is This Worm Kosher? The Kashrus of Tolayim in Fish, OU Kosher (SEPT. 22, 2006), http://oukosher.org/blog/consumer-kosher/is-this-worm-ko sher-the-kashrus-of-tolayim-in-fish/ [hereinafter Is this Worm Kosher?].

32. Is this Worm Kosher?, supra note 32.

33. Id. This argument speculates that the Talmud is referring to a specific type of insect, and, because we cannot distinguish precisely which insects are considered non-kosher, even when found in the flesh, we must assume that that they are all prohibited. Id. The general practice nowadays is to refrain from eating any insects. $I d$.

34. Id. 
located in the flesh itself. ${ }^{35}$ The worms were found to have originated in the flesh, and the OU therefore allowed its supervisors to certify that canned sardines are kosher. ${ }^{36}$

Specific fish parasites also cause problems. A worm called anisakis has been found in certain species of seafood, leading prominent Israeli rabbis to prohibit their consumption in the absence of thorough prior inspections. ${ }^{37}$ Most kashrut agencies, including the Orthodox Union, have been lenient in their rulings. ${ }^{38}$ But modern technology has generated even more intense scrutiny, which has ostensibly created a whole new range of foods Orthodox Jews can or cannot eat - but only through paying inflated prices for special kosher brands. ${ }^{39}$

All of these rules, along with others concerning Jewish life, were codified in 1563 by Joseph Karo and published in Venice two years later as the Shulchan Aruch (literally the "Set Table"). ${ }^{40}$ Together with its commentaries, it is the most widely accepted compilation of Jewish law, and contains virtually of all the strict rules governing food preparation still followed today by Orthodox and many Conservative Jews. ${ }^{41}$ Even non-Jews are held to be accountable for seven major prohibitions governing morality - the "so-called Noahide [laws]", the divine restrictions made applicable to all humanity after the Great Flood - including the prohibition against eating the limb of a live animal. $^{42}$

But Judaism is not the only religion to have a distinct set of dietary laws. In Islam, the guidelines are derived from the Qur'an. ${ }^{43}$ As with kosher laws, the restrictions are divided into prohibited types of food and methods of preparation. ${ }^{44}$ Halal forbids both animals not slaughtered properly and those not killed in the name of Allah. ${ }^{45}$ Also for-

35. Worms In Canned Fish Found Kosher By DNA Analysis, FailedMessiah.com (Feb. 13, 2012), http://failedmessiah.typepad.com/failed_messiahcom/2012/02/annals-of-kosher-supervi sion-worms-in-fish-234.html [hereinafter Worms in Canned Fish].

36. Id.

37. See Haredi Rabbinic Leaders Ban Most Fish, FailedMessiah.com (Apr. 25, 2010), http:// failedmessiah.typepad.com/failed_messiahcom/2010/04/haredim-ban-most-fish-123.html.

38. See Is this Worm Kosher?, supra note 32.

39. See, e.g., Worms In Canned Fish, supra note 36.

40. See Dana Evan Kaplan, The New Reform Judaism: Challenges and Reflections 350 (2013).

41. Asriel Rosenfeld, Shulchan Aruch, TORAH.ORG, http://www.torah.org/advanced/shulchanaruch/ (last visited Oct. 14, 2014).

42. Alan Cecil, Reinventing the Noahide Movement, Hesedyahu (June 5, 2014), https:// hesedyahu.wordpress.com/page/2/.

43. See generally Qur'an 2:173, 5:3, 6:145 and 16:115; see also Nick Eardley, What is Halal Meat?, BBC UK (May 12, 2014), http://www.bbc.com/news/uk-27324224.

44. See generally Qur'an 2:173, 5:3, 6:145 and 16:115.

45. See Qur'an 2:173, 5:3, 6:145. 
bidden are carnivorous mammals; ${ }^{46}$ pork and byproducts of pork ${ }^{47}$ (e.g., marshmallows, gelatin, Jell-O); animals dead prior to slaughtering; ${ }^{48}$ blood and its byproducts; ${ }^{49}$ birds of prey; ${ }^{50}$ and all manner of alcohol..$^{51}$

Another similarity between Jewish and Islamic dietary laws is the intention that animals be slaughtered in a way that limits their pain and suffering. This involves severing the jugular vein so that oxygen is cut off to the brain and pain receptors. ${ }^{52}$ Blood is then drained from the carcass as much as practical. .53

In Hinduism cows are sacred, revered for their gentle nature and strength. Hindus do not in fact "worship" cows, but they believe that all life has a soul and that killing them would be sinful. ${ }^{54}$ Thus, must Hindus do not eat beef, although they rely on cows for dairy products and for tilling fields. ${ }^{55}$

\section{Kashrut in Early America}

The perceived need for kosher supervision in the United States can be traced to colonial times. As early as 1660, a Portuguese Jew "applied for a license to sell kosher meat in New Amsterdam,"56 and controversies about what's kosher and what's not date almost as far back. In the latter part of the Eighteenth Century, for example, an internecine kashrut dispute arose between two noted rabbis who had differ-

46. Compare 1 Ibn Rushd, The Distinguished Jurist's Primer 532 (Imran Ahsan Khan Nyazee trans., 1994), with Majid KHadduri, AL-ShâfI'l's Risâla: Treatise on the FoundaTIONS OF IsLAmic JuRISDPRUdENCE 191 (2d. ed., Islamic Texts Society 1987) (prohibiting "beasts possessing fangs").

47. See Qur'an 2:173, 6:145.

48. See Qur'an 2:173, 6:145, 16:115

49. See Id.

50. See Sahih Muslim 21:475.

51. See Qur'an 5:90.

52. See, e.g. I.M. Levinger, Physiological and General Medical Aspects of Shechita, in Shechita: Religious Historical and Scientific Aspects 99, 192-95 (Philipp Feldheim Inc. 1976); Halal: what is halal meat and is it inhumane?, THE WEEK, May 8, 2014, http://www .theweek.co.uk/uk-news/58447/halal-what-halal-meat-and-it-inhumane.

53. Id:; see Eardley, supra note 44. Despite the similarities discussed above between kashrut and halal, no cases have been reported as challenging the constitutionality of any halal fraud statute as of October 14, 2014. See, e.g., Elijah L. Milne, Protecting Islam's Garden from the Wilderness: Halal Fraud Statutes and the First Amendment, 2 J. Food L. \& Pol'y 61, 72 (2006).

54. The Cow in Hinduism: Why is the cow important to Hindus?, ReLigion Facts, http://www .religionfacts.com/hinduism/things/cow.htm (last visited Jan. 14, 2015).

55. Dwijendra Narayan Jha, The Myth of the Holy Cow 17 (2002).

56. Eliezer Eidlitz, Is it Kosher? Encyclopedia of Kosher Foods, Facts and FallaCIEs 31 (5th ed. 2004). 
ing views of what constitutes scales on fish. ${ }^{57}$ The widely accepted position was that scales must be removable by hand or knife. ${ }^{58}$ In the late 1700s, Rabbi Ezekiel Landau declared that it was permitted to eat sturgeon, whose scales could be removed by using a tool or soaking the whole fish in an abrasive liquid. ${ }^{59}$

The first recorded complaint regarding the sale of non-kosher meat came in 1771 against the Shochet Moshe. ${ }^{60}$ Another claim against a shochet (ritual slaughterer) came in 1774 , and led to the first court case involving kashrut. ${ }^{61}$ The result was invalidation of the license of a kosher butcher. ${ }^{62}$

The Jewish communities, as they developed in the United States, followed the European tradition of appointing community shochtim, who could be administratively removed if they "did not follow strict guidelines." 63 The practice of administratively removing the shochtim "changed dramatically in 1813" when a man named Avraham Jacobs "became the first independent shochet in the United States." ${ }^{64}$ Many more independents followed, which ultimately led to a substantial decline in the standard of kashrut. ${ }^{65}$

By the early part of the Nineteenth Century most American Jews were ignorant of (if not indifferent to) the dietary laws. ${ }^{66}$ Jewish communities were largely in disarray. ${ }^{67}$ Even in New York, which had over 80,000 Jews in 1880 , there was no central Rabbinic authority. ${ }^{68}$

In 1840, the first ordained rabbi, Abraham Rice of Bavaria, arrived in the United States. ${ }^{69} \mathrm{He}$ was a learned old-school teacher and an

57. See Solomon B. Freehof, The Responsa Literature 162 (Ktav Publ'g House, Inc. 1973) (1955)

58. See id. "[Nahmanides] describes the shape of the scales and says that the scales must be fixed in the skin yet be removable by hand or by knife, otherwise the fish is not kasher. Id. This new test suggested by Nahmanides was embodied in the later codes." Id.

59. Id. at 162-163. Ezekiel Landau was seen as the preeminent Jewish legal authority of his time and, rather than confront him on the merits, many orthodox rabbis claimed that he had retracted his ruling before his death. Id. at 164-65. Samuel Landau (Ezekiel's son) wrote a spirited refutation of that assertion, upholding his father's original ruling. See id.

60. EidLITZ, supra note 60 , at 31 .

61. Id.

62. Id.

63. Id.

64. Id.

65. EIDLITZ, supra note 60 , at 31.

66. See, e.g. I. Harold Sharfman, The First Rabbi 142 (Pangloss Press, 1988).

67. See, e.g. Timothy D. Lytton, Kosher: Private Regulation in the Age of Indus. Trial FoOd 10 (Harvard University Press, 2013).

68. Id. at 20.

69. ShARFMAN, supra note 69 , at 42 . 
"uncompromising opponent" of Reform Judaism. ${ }^{70}$ After a brief attempt to revive the Jewish community of Newport, Rhode Island, he was hired as the spiritual leader of Congregation Nidchei Yisroel in Baltimore. $^{71}$

Rabbi Rice urged upon American Jews "the great importance of selecting a spiritual chief ... for the purpose of regulating our spiritual affairs [because it is surely necessary] to prevent the uninitiated from giving their crude decisions which are but too well calculated to do permanent injury to our faith."72 His strident and continuing campaign against lax observance of the Sabbath and dietary laws, not to mention widespread assimilation, brought him into conflict with many of his congregants. ${ }^{73}$

In 1863, a group of laymen and shochtim tried unsuccessfully to form an organization that would improve and maintain kashrut standards. ${ }^{74}$ Beginning in 1886, however, several Orthodox congregations had joined together, and the newly created Association of American Orthodox Hebrew Congregations appointed Rabbi Jacob Joseph of Vilna, Lithuania, for the same purpose, to implement kashrut standards in America. ${ }^{75}$

In July of 1888, Rabbi Joseph, delegated the first Chief Rabbi of New York, arrived in the port town of Hoboken, New Jersey, where he quickly undertook the daunting task of organizing New York's kosher meat business according to much stricter standards. ${ }^{76}$ To cover the cost of mashgichim (kosher supervisors), one cent was added to the price of every bird killed in the slaughterhouses under the Chief Rabbi's purview. ${ }^{77}$ In order to indicate the chicken had been ap-

70. Rice, Abraham, JEwISH ENCYCLOPEDIA, http://www.jewishencyclopedia.com/articles/ 12738-rice-abraham (last visited Feb. 10, 2013).

71. See Sharfman, supra note 70, at 73.

72. Abraham Rice, Editorial Correspondence, Rev. Mr. Rice's Letter, 2 The Occident 599-60 (1845), reprinted at http://www.jewish-history.com/occident/volume2/mar1845/editorial.html.

73. See Israel Tabak, Rabbi Abraham Rice of Baltimore, Pioneer of Orthodox Judaism in America, 7 Tradition 102, 107-08 (1965). When he decreed that Sabbath-breakers should not be called to the Torah, there was such resistance that he had to back down; but he insisted that while they could be called up, nobody should answer "amen" to the blessings they recited. SHARFMAN, supra note 70, at 132. After an 1842 incident in which he objected to Masonic rites held at a Jewish funeral, some members left the congregation and founded the Har Sinai Verein, the first lasting Reform congregation in the United States. Id. at 133.

74. EIDLITZ, supra note 60, at 31.

75. See Howard Sachar, History of Jews in America 191 (1992).

76. Id. at 191-92.

77. Shmuel Singer, "A Chief Rabbi for New York," http://tzemachdovid.org/gedolim/jo/tpersonality/rij. html (last visited Apr. 29, 2013); see also Shechita in America: Past and Present, A Brief Overview, OU Kosher (May 5, 2004) http://oukosher.org/blog/consumer-kosher/shechitain-america-past-and-present-a-brief-overview/ [hereinafter Shechita in America]. 
proved by a kosher supervisor, the mashgichim were also responsible for affixing a plumba (lead seal) to the poultry bearing the Chief Rabbi's official name and title: "Harav Hakollel R' Yacov Yoseph."78

But the more stringent standards were not popular with many butchers and independent shochtim, and some rabbis as well feared the loss of income they had been receiving for kashrut supervision. ${ }^{79}$ The practice was likewise criticized by the Yiddish press, claiming that it "smacked of price-gouging", like the "hated state tax on kosher meat imposed in Pale of the Settlement." 80

Meanwhile, that tax was not paid by any one. ${ }^{81}$ "Kosher price gouging" thus became a slogan in the non-Orthodox and radical press. ${ }^{82}$ The weekly Der Volksadvokat published a poem on its front page which spoke of "Orthodox chickens ... dancing [while] wearing shiny lead plumbas [so] that the Chief Rabbi will live on a fat salary." 83 Chassidim from Galicia appointed their own Chief Rabbi of America; Ukrainian Chassidim followed suit. ${ }^{84}$

Unhappy religious officials staged public meetings contending that they had neither chosen nor accepted Rabbi Joseph as their Chief Rabbi. ${ }^{85}$ In the spring of 1895 , the retail butchers joined forces to "reject[ ] entirely the Chief Rabbi's supervision", leaving him "virtually powerless." 86 Two years later, the shochtim themselves joined to form a union called "Meleches Hakodesh," ostensibly to "improve kashrut standards" and to advocate for higher wages. ${ }^{87}$ Some Orthodox congregations that had originally supported the idea of a chief rabbi now declined to pay Rabbi Joseph. ${ }^{88}$ Perhaps as a result of the tensions and pressures, Rabbi Joseph suffered debilitating strokes and according to the Yiddish paper Forverts (now The Jewish Daily Forward), he had become a "sacrificial offering to business-Judaism." 89

Kashrut supervision in New York soon fell into the hands of food processors and distributors, butchers, and slaughterhouse owners, not

\footnotetext{
78. Shechita in America, supra note 81.

79. SACHAR, supra note 79, at 192.

80. Id.

81. Id.

82. Shechita in America, supra note 81.

83. Id. (internal quotation marks omitted).

84. SaChar, supra note 79, at 192 . The Galicians chose Joshua Segal; the Ukranians chose Chaim Vidrowitz. Id.

85. Shechita in America, supra note 81.

86. Id.

87. EidlitZ, supra note 60 , at 31.

88. SACHAR, supra note 79, at 192-3.

89. Id. Rabbi Joseph died on July 28, 1902 at the age of 59. Death of Chief Rabbi Jacob Joseph, N.Y. TImes, July 29, 1902, at p. 9.
} 
to mention "rabbis" whose primary motivation was clearly more financial gain than adherence to religious doctrine. 90 The kosher food industry also came to be "infiltrated by corrupt labor-union bosses" and organized crime syndicates.91 For the few honest rabbis who struggled to maintain kashrut standards, "it was often a bruising and ultimately losing battle."92

Chicago had a similar experience. In September 1903, Rabbi Jacob David Willowsky was publicly installed as Chief Rabbi of the Chicago Orthodox congregations. ${ }^{93}$ Like Jacob Joseph in New York, Rabbi Willowsky was immediately critical of the kosher butchering practices he saw in Chicago and embarked upon upgrading the city's kashrut standards. ${ }^{94}$ In short order, he got into a big dispute with the reigning kashrut supervisor in Chicago, and a predictable uproar followed. ${ }^{95}$ In the summer of 1904, just a year after he arrived, Rabbi Willowsky resigned his position and left the world of kashrut supervision altogether, eventually establishing a yeshiva in the somewhat more sedate surroundings of Safed, Israel. ${ }^{96}$

\section{B. From Community Regulation to Big Business}

Indeed kashrut in America had by now become big business. ${ }^{97}$ Though kosher meat was more expensive, the market for it increased dramatically in the early Twentieth Century. ${ }^{98}$ By 1917, American Jews were consuming well over 150 million pounds of ritually slaughtered beef a year. ${ }^{99}$ But as might be expected in a capitalist environment, non-meat products labeled as kosher were also beginning to appear in the broader American market. ${ }^{100}$ Profit is not always influenced by morality.

Unlike Europe, which had a central kashrut authority, U.S. butchers and slaughterhouses engaged their own "rabbis" as supervisors. The arrangement was lucrative for all, but the standards were lax. By

90. Rabbi Berel Wein, Rabbi Alexander Rosenberg, The Truly Kosher Jew, RabBiWein.com, http://www.rabbiwein.com/blog/rabbi-alexander-rosenberg-the-truly-kosher-jew-357.html (last visited Oct. 14, 2014).

91. Id.

92. Id.

93. Aaron Rothkoff, The American Sojourns of Ridbaz, 57 AJHS QUARTERLY 566, 557 (1968).

94. Id. at 566-67.

95. See generally, id. at 568-570.

96. Id. at 571 .

97. SACHAR, supra note 79, at 192-3.

98. See id.

99. Id.

100. Id.; EIDLITZ, supra note 60, at 32. 
some estimates, possibly half of all meat sold as kosher was in fact not kosher. ${ }^{101}$

Seeking to apply some regulatory scheme that might guard against kosher fraud, a chemist named Abraham Goldstein set out to persuade both importers and domestic food processors to add kosher certifications to their products. ${ }^{102}$ In 1924, Goldstein was appointed the first director of the Union of Orthodox Congregations (or "OU," which had just entered the kosher supervisory business after having been founded twenty-six years earlier as a national Jewish outreach organization) ${ }^{103}$ and entered the supervisory business. ${ }^{104}$

Tensions between rabbis and private shochtim nevertheless continued to abound around the country, the former insisting on upgrading standards and the latter resisting any change to the way they were handling their businesses. ${ }^{105}$ As the Chief Rabbi of Cleveland, Yehuda Levenberg wrote to Rabbi Eliezer Silver of Cincinnati:

$[\mathrm{N}]$ on-Jews stand right next to the [shochtim]. While the latter [ritually] slaughter, the former kill the chickens. Time after time the dead chickens are mixed up. Those killed are sold as kosher, while the kosher slaughtered are mistakenly considered non-kosher. The salaries of the [shochtim] vary in accordance with their speed. They average about thirty-five dollars a week. There is one who actually earns over one hundred dollars a week. This [shochet] employs his own Rabbi to supervise him. ${ }^{106}$

Rabbi Levenberg likewise experienced great difficulties in trying to enforce the traditional rules of kashrut, becoming embroiled in an ugly battle of greed and power, especially when evidence emerged of racketeering among local butchers. ${ }^{107}$ After the bombing of a local poultry market, he was wrongly arrested and briefly jailed. ${ }^{108}$ The Cleveland City Council eventually apologized for the mistake. ${ }^{109}$

101. SACHAR, supra note 79, at 192. Unlike the governments of Europe, federal and local governments in the U.S. would not attempt to interfere with these religious affairs. See id. For an interesting snapshot of kashrut in New York in the early Twentieth Century, see JEwISH CoMmunity of New York City, The Jewish Communal Register of New York City $1917-$ 1918, 312-17 (2d ed.).

102. EidLITZ, supra note 60 at 32.

103. Harold Gastwirt, Fraud, Corruption, and Holiness 98 (1974).

104. Eidlitz, supra note 60 , at 32 . In 1935 , Goldstein founded a new certifying agency, the Organized Kashrut Laboratories ("OK"). Id.

105. See Aaron RakefFet-Rothkoff, The Silver Era 131-33, 136-37 (1981).

106. Id. at 136. The letter was dated September 26, 1932. Id. at $136 \mathrm{n} .11,153$.

107. Id. at 137; "Racketerring War" Leads to Arrest of Yeshiva Dean; Police Apologize; Dismiss Charges, Jewish Telegraphic Agency (Jan 26, 1933).

108. Racketerring War, supra note 111.

109. Id. 
At the semi-annual convention of the Union of Orthodox Rabbis of America and Canada in November of 1930, a resolution was adopted that prohibited joint ownership of kosher and non-kosher meat companies. ${ }^{110}$ Over time, things slowly began to improve. In May of 1932, a new Kashrut Association of Greater New York was established. ${ }^{111}$ Shochtim were to be paid not for animal or chicken slaughtered, but a fixed salary. ${ }^{112}$ Rabbinic supervisors were to be hired by the community, not by the butchers themselves. ${ }^{113}$

By the 1930s, there were hundreds of butchers in every major American city who called themselves kosher. ${ }^{114}$ But some religious historians view this time period as "a golden era for cheaters."115 Rabbis in Baltimore took out an ad in the local Jewish newspaper appealing to Jewish housewives not to rely on the Hebrew sign on a butcher shop that read "Kosher." At the bottom of the notice was a message in Yiddish: "Koift nisht fun die chislers!" ("Don't buy from the cheaters!"). ${ }^{116}$ In one local incident, "genuine" kosher hot dogs were imported from New York and widely consumed, until it was discovered that they were not kosher at all.117

In fact, there seemed to be a never-ending series of kashrut scandals at the time, many involving leading rabbis in New York. ${ }^{118}$ Much of this was reported in the New York Times and later catalogued in a book by Harold Gastwirt entitled Fraud, Corruption, and Holiness - a kosher version of Upton Sinclair's classic 1906 muckraking of the meatpacking industry, The Jungle. ${ }^{119}$

Despite the efforts of the OU and individual rabbis, strict kosher supervision continued to be hindered by business proprietors and shochtim with vested interests. ${ }^{120}$ In the summer of 1934, a major dispute erupted in New York between shochtim and butchers regarding the cost of supervision. ${ }^{121}$ The shochtim claimed that they had to

110. RAKEFFET-ROTHKOFF, supra note 109 , at 141.

111. Id. at 147 .

112. See id. at 138 (referring to "regulations contained in an August 27, 1929 letter to Rabbi Silver from the Rabbincal Council of the Orthodox Rabbis of Toronto." Id. at $137 \mathrm{n.13,153).}$

113. Id.

114. Interview with Dovid Katz, The John Hopkins University (Oct. 2013). Prof. Dovid Katz, a historian of Jewish Baltimore, wrote an article on the subject entitled, "Joe," based on his own interview with an elderly Baltimore butcher named Joe Shavrick. The article appeared in a local publication, WhatWhereWHen issued Summer 2008 [original with Author].

115. Id.

116. Id.

117. $I d$.

118. See generally GastwirT, supra note 107.

119. Id. Upton Sinclair, The Jungle (Singet Classics 1906).

120. RAKEFFET-ROTHKOFF, supra note 109, at 147.

121. Id. 
slaughter too fast, that the supervising rabbis were not thorough, and that there was no proper identifying mark on kosher birds that were slaughtered. ${ }^{122}$ New York Mayor Fiorello LaGuardia appointed Otto Rosalsky, a judge in the Court of General Sessions and an Orthodox Jew, to mediate. ${ }^{123}$ Judge Rosalsky ultimately determined that "all kosher slaughtered poultry offered for sale shall have affixed there to a plumba [lead seal] signifying that it is kosher, the same to be placed thereon by a mashgiach."124 "The plumba shall be supplied by the Kashrut Association of Greater New York." ${ }^{125}$ A ban was imposed on those who did not comply. ${ }^{126}$

Although the differing interests of shochtim, rabbis, and unions all served to underscore what appeared to be their primary motivation (profit), ${ }^{127}$ after World War II, the business of kosher supervision became somewhat more focused on kashrut standards. ${ }^{128}$ This was likely the result of the waves of new kosher consumers, many of them Holocaust refugees, ${ }^{129}$ then entering the country.

It also reflected the increasingly charismatic leadership of the Orthodox Union. ${ }^{130}$ Organized supervision under the OU did not begin to reach its full flower until the mid-Twentieth Century, with the appointment of Rabbi Alexander Rosenberg as the group's rabbinic administrator. ${ }^{131}$ According to one Jewish historian, Rabbi Rosenberg "combined within himself old-world charm, a shrewd understanding of people and their true motives, an uncanny business sense, unimpeachable integrity, enormous compassion for individuals and a sense of public service that always allowed him to see the big picture and not just the narrow case in front of him." 132

Rosenberg was an accomplished scholar, descended from a long line of distinguished Hungarian rabbis, and he would "not allow compromises in kosher standards." 133 While he understood the problems

122. Id.

123. Id.

124. Id.

125. RAKEFFET-RothKofF, supra note 109 , at 147.

126. See id.

127. See, e.g., Local 167 of International Brotherhood of Teamsters, Chauffeurs, Stablemen \& Helpers of America et al. v. United States, 291 U.S. 293 (1934) (dispute in late 1920's about control of the poultry market in New York).

128. See, e.g., RakefFet-RothKoff, supra note 109 , at 151.

129. SACHAR, supra note 79 , at 696 . Sachar reports that around 100,000 Jews entered the country between 1947 and 1950. Id. "Nearly half of these were from Chassidic backgrounds." Id. Another 600,000 of various backgrounds entered by 1990. Id. at 898 .

130. See LYTTON, supra note 71 , at $46-53$.

131. Id. at 46.

132. Wein, supra note 94.

133. Id. 
of mass food production, he "envisioned the day" that an observant Jewish consumer would be able to walk into "any supermarket in North America and purchase kosher food, supervised by the OU."134 $\mathrm{He}$ "impressed upon major American food companies" - ColgatePalmolive, H.J. Heinz, Procter and Gamble, Best Foods, and others the financial advantages of "kosher production and supervision."135 He was helped by what has been described as his "aristocratic manner, his handsome appearance and immaculate dress, his integrity, his wisdom and his faith."136 To the non-Jewish businessmen, the rabbis placed in control of their inventories and suppliers were simply "bless[ing] their machinery."137

Over the next several decades, small slaughterhouses sprang up in the hinterlands, far from the main cities and Jewish communities. Higher standards could thus be more easily implemented, and consumer-protection law more readily justified. ${ }^{138}$ At the same time, however, kosher consumers could bear witness to the fact that the constitutional separation of church and state was being stretched to its limits, and perhaps beyond.

\section{Governmental Intervention and Involvement}

In colonial America various laws were put into place to regulate trade, some of which had to do with food safety, such as setting weight standards and inspecting exports of "embalmed meat."139 After 1776, ensuring the purity of comestibles was left largely to the states. ${ }^{140} \mathrm{By}$ the middle of the 19th Century, increasing industrialization and technological advances had a substantial effect on the food industry. ${ }^{141}$ Chemical preservatives enabled the transportation of shipments across the country quickly and in large quantities. ${ }^{142}$ In the 1870 s, a "Pure Food Movement" had begun to advocate for laws to protect consumers against adulterated food products. ${ }^{143}$

134. Id.

135. Id.

136. Id.

137. Wein, supra note 94.

138. See John P. Swann, History of the FDA, in The Food and Drug Administration 10, 13 (Meredith A. Hickmann ed., 2003).

139. See James Harvey Young, The Long Struggle for 1906 Law, The Food And Drug AdMinistration 17, 21 (Meredith A. Hickmann ed., 2003).

140. Swann, supra note 142, at 10.

141. See, e.g. Young, supra note 143, at 17-18.

142. Id.

143. Wallace F. Janssen, The Story of the Laws Behind the Labels, in The Food AND Drug Administration 23, 24 (Meredith A. Hickmann ed., 2003). For a discussion of the evolution of kosher certification agencies, see infra Part IV.B. 
But prior to the Twentieth Century, there was virtually no federal oversight of domestically produced food. ${ }^{144}$ Even then, it took the efforts of a muckraking journalist, the aforementioned Upton Sinclair, to stir public sentiment and spur government action. ${ }^{145}$

The Pure Food and Drug Act of 1906 did not define food standards, but it did prohibit the addition of "any ingredients that would substitute for the food, conceal damage, pose a health hazard, or constitute a filthy or decomposed substance."146 Misbranding - making "false or misleading label statements regarding a food" - was now illegal. ${ }^{147}$ With the rapid advances in food science and technology the 1906 Act quickly became obsolete, but it was extensively amended throughout the first half of the century, eventually coalescing into the Food, Drug, and Cosmetic Act of 1938. ${ }^{148}$ The most recent effort to regulate food safety was the Food Safety Modernization Act, which was signed into law in January of $2011 .{ }^{149}$

\section{The Special Case of Milk}

According to anthropologists, humans did not drink milk regularly until the domestication of animals during the Neolithic period - that is, upon the invention of agriculture, which seem to have occurred as early as $9000-7300$ B.C. in Southwest Asia ${ }^{150}$ and around 3500-3000 B.C. in Central America. ${ }^{151}$

Dairy farming appeared in Europe around 7000 B.C. and reached Britain and Scandinavia by 4000 B.C. ${ }^{152}$ The consumption of milk and dairy products did not become common in the Americas until rela-

144. Lorine S. Goodwin, The Pure Food and Drink Crusaders 14 (McFarland 2006).

145. GoodwiN, supra note 149, at 250-51 (noting that President Theodore Roosevelt ordered "a drastic and thoroogoing [sic]' federal inspection of all stockyards, packinghouses and their products" as a result of Sinclair's book).

146. Swann, supra note 142, at 11.

147. Young, supra note, 143, at 21 . The Act also prohibited "interstate and foreign commerce in adulterated and misbranded food and drugs." Id.

148. Swann, supra note 142, at 10-11; FDA History - Part II, U.S. Food AND DrUG Adminis. TRATION, http://www.fda.gov/AboutFDA/WhatWeDo/History/Origin/default.htm (last visited Nov. 26, 2013).

149. Food Safety Modernization Act, Pub. L. No. 111-353 (2011). The official and authoritative source of the FSMA is the version offered by the Government Printing Office (G PO), available at http:/www.gpo.gov/fdsys/pkg/PLAW-111publ353/pdf/PLAW-111publ353.pdf. See also Margaret A. Hamburg, What Does the New Food Safety Law Mean for You?, FoodSAFETY .Gov. (Jan. 5 2011), http://www.foodsafety.gov/blog/fsma.html. Dr. Hamburg is the Commissioner of Food and Drug Administration.

150. Peter Bellwood, First Farmers: The Origins of Agricultural societies 46 (2005).

151. Id. at 151 .

152. T. Douglas Price, Europe's First Farmers: An Introduction, in Europe's First Farmers 1,3 (T. Douglas Price, ed. 2000). 
tively recently - probably over the last 500 years. ${ }^{153}$ Today there are more than " 6 billion consumers of milk and milk products, the majority of them in developing countries." 154 In 2010, the world's dairy farms produced over 710 million tons of milk. ${ }^{155}$

Many religions consider cows sacred including, Hinduism, Jainism, and Buddhism. ${ }^{156}$ Some countries, thus, prohibit the slaughtering of cattle, although that taboo does not always extend to taking their milk. ${ }^{157}$ India, for example, is the world's largest producer and consumer of milk. ${ }^{158}$

Vegans also do not consume dairy products. ${ }^{159}$ They object to what they perceive to be inhumane treatment of cattle, such as the slaughter of the male offspring of dairy cows, the routine separation of mother and calf soon after birth, and the culling of cows after their productive lives. ${ }^{160}$

In 1863, Louis Pasteur, a French microbiologist, invented a method of killing harmful bacteria in beverages. ${ }^{161}$ It involved "heating the liquid to a particular temperature for a set time,"162 and was first used as a means of preventing wine and beer from going sour. ${ }^{163}$ In 1884 , Dr. Harvey Thatcher of Pottsdam, New York, invented an all-glass

153. See Historical Timeline: History of Cow's Milk from the Ancient World to the Present, ProCon.org (July 10, 2013), http://milk.procon.org/view.timeline.php?timelineID=000018.

154. Food \& Agric. Org. of the U.N., Pro-Poor Livestock Policy Initiative: Status and Prospects for Smallholder Milk Production A Global Perspective (2010), available at $\mathrm{http}: / / \mathrm{www}$.fao.org/docrep/012/i1522e/11522e00.pdf.

155. Food Outlook: Global Market Analysis, Food \& AGRIC. ORG. OF THE U.N. 57100 (2012), http://www.fao.org/docrep/016/al993e/al993e00.pdf.

156. See The Cow in Hinduism: Why is the cow important to Hindus?, Religion Facts http:// www.religionfacts.com/hinduism/things/cow.htm (last visited Nov. 26, 2013).

157. See, e.g. The Karnataka Prevention of Cow Slaughter and Cow Preservation Act of 1964, No. 35 of 1964, KARNATAKA Acrs (1964) (India), available at http://dpal.kar.nic.in/ .$\% 5 C 35 \% 200 f \% 201964 \% 20(E)$.pdf (providing a law within a state of India that bans the slaughtering of cows).

158. Dep't of Animal Husbandry, Dairying \& Fisheries, Ministry of agriculture, ANNUAL REPORT 2011-12 (2012) (India) 10, available at http://www.dahd.nic.in/dahd/WriteReadData/Annual\%20Report\%20English\%202011-12.pdf.

159. Vegan, DictionaRY.COM, http://dictionary.reference.com/browse/vegan?s=t (last visited Nov. 22, 2014).

160. See, e.g., The Dairy Industry, PETA.orG, http://www.peta.org/issues/animals-used-forfood/dairy-industry.aspx (last visited March 7, 2013).

161. Rodney Carlisle, Scientific American Inventions and Discoveries 284-85 (2004).

162. Pasteurization and Regulation of Milk in History, Living History Farms Blog (Sept. 24, 2011), http://livinghistoryfarms.wordpress.com/2011/09/24/pasterization-and-regulation/ [hereinafter Pasteurization].

163. See id. 
milk bottle, which was marketed as "Thatcher Milk Protector."164 Thatcher, thus, became known as "the father of the milk bottle."165

But by the early Twentieth Century, there was still virtually no government regulation of dairy products in the United States, either on the farm or at the market. ${ }^{166}$ Farmers would take raw milk from the cow and, usually after separating the cream to make butter, sell it to consumers. ${ }^{167}$ Pasteurization of milk thus became the norm and the law. ${ }^{168}$

Nowadays virtually all food consumed by the public, both in grocery stores and in restaurants, is subject to federal regulations. ${ }^{169}$ As food providers, modern farms are inspected under laws governed generally by the FDA. ${ }^{170}$ Milk has been regulated in some way for over 100 years, most importantly with "laws regarding pasteurization and homogenization," as well as with regulations "regarding the transport of milk" and milk products. ${ }^{171}$

The rabbis differ as to the rules governing milk. All agree that milk from animals that are deemed unclean (treif) - that is, those that are ill or injured, or specifically prohibited by the Torah (such as pigs) - is not kosher. ${ }^{172}$ But one may consume only cholov yisroel, or milk that is produced when a Jew observes the actual milking process and verifies that none of the milk has come from a non-kosher animal species. ${ }^{173}$ Although this restriction is endorsed by many Orthodox

164. See Bill Lockhart, The Dairies and Milk Bottles of Otero County, New MexICO AT 12-13 (2011), available at http://www.sha.org/bottle/pdffiles/oterochap2a.pdf.

165. Id. at 13 .

166. Andy Weisbecker, A Legal History of Raw Milk in the United States, 69 JourNAL OF ENVIRONMENTAL HEALTH 62 (April 2007), available at http://www.marlerclark.com/pdfs/rawmilk-jeh.pdf.

167. See Jim Phillips \& Michael French, State Regulation and the Hazards of Milk, 1900-1939, 12 Soc. Hist. OF MED. 371, 371 (1999); see also CARLisle, supra note 165, at 357.

168. See Food Code, supra note 2, at ii; see also Daniel A. Sumner \& Joseph V. Balagtas, United States' Agricultural Systems: An Overview of U.S. Dairy Policy, EnCYClopedia of DAIRY SCIENCES (2002), available at http://aic.ucdavis.edu/research1/DairyEncyclopedia_policy .pdf; Wendy Cole, Got Raw Milk? Be Very Quiet, Time (Mar. 13, 2007), available at http://www .time.com/time/health/article/0,8599,1598525,00.html (describing pasteurization process and detailing legal troubles of raw milk producers).

169. See, e.g., Food Code, supra note 2.

170. See generally, id.

171. See Pasteurization, supra note 166.

172. See Shulchan Aruch: Part II: Yoreh De'ah, Chapter 2 - Life and Death; Sources; Body Parts, TORAH.ORG, http://torah.org/advanced/shulchan-aruch/classes/chapter2.html (last visited Feb. 22, 2013).

173. See Ou-D and Cholov Yisroel, OU KosHer, http://oukosher.org/faqs/what-is-the-differ ence-between-oud-and-oud-cholov-yisrael/ (last visited Dec. 10 2014). 
rabbis, ${ }^{174}$ one of the most respected halachic scholars of the Twentieth Century, Rabbi Moshe Feinstein, ruled that the designation cholov yisroel is unnecessary because the regulations imposed on the U.S. milk industry by the USDA are so stringent that anything labeled "cow's milk" can be fully trusted. ${ }^{175}$

\section{Kosher Slaughter}

Fledgling Jewish communities in the United States originally followed the European tradition of appointing kosher slaughterers (shochtim) who could be removed if they failed to follow the strict rules laid down by the Torah as interpreted by the rabbis. ${ }^{176}$ This system changed dramatically when a man named Avraham Jacobs hung up his shingle as the first independent shochet in America. ${ }^{177}$ Many more soon followed in his footsteps. ${ }^{178}$ One result of this entrepreneurship was a decline in the standards required to ensure that meat was kosher. ${ }^{179}$ It was not until 1897 that the shochtim themselves, realizing the extent of the problem, banded together to form the Meleches Hakodesh union - whose goals were both to improve kashrut standards and increase their wages. ${ }^{180}$

Kosher consumers, who once had to rely primarily on their own level of commitment to adhere to the dietary laws - and ultimately still do - were now aided by religious leaders and purveyors of meat and dairy products whom they trusted. With processed and packaged foods becoming more widespread in America, they could also depend upon food-labeling regulations to help them make informed decisions. ${ }^{181}$

174. See, e.g., Rav Moshe Zt'l's Heter of Cholov Stam Revisited, Ou Kosher, (Dec. 22, 2008) http://oukosher.org/blog/consumer-kosher/rav-moshe-ztls-heter-of-cholov-stam-revisited/ (citing Yoreh Deah 115:1, from Maseches Avodah Zarahdaf 35b) [hereinafter Rav Moshe].

175. Compare "25th Yahrzeit of Harov Moshe Feinstein," THE FIvE Towns, http://www .thefivetowns.info/today/12434-25th-yartzeit-of-harov-moshe-feinstein.html (last visited March 7, 2013), with How Kosher Is Your Milk?, Jewish JourNal (June 7, 2012), http://www.jewishjour nal.com/socialjusticerav/item/rabbi_herschel_schachters_chumra_on_milk_abuse_in_the_dairy_ industry_201206. Rabbi Hershel Schachter, a prominent rosh yeshiva at Yeshiva University, has made the bold claim that, because with modern dairy farm equipment milk from the minority of non-kosher cows is invariably mixed with that of the majority of kosher cows, no milk from a large dairy operation is kosher. See id. The Orthodox Union, however, rejects this point of view. See Rav Moshe, supra note 178.

176. EidLITZ, supra note 60 , at 31 .

177. Id.

178. Id.

179. Id.

180. Id.

181. See, e.g., Eidlitz, supra note 60, at 11-29 (listing reliable kosher certifications). 
As the packaged-food industry burgeoned, however, the ability to check for non-kosher ingredients became considerably more difficult. In 1924, the OU entered the kosher supervision business. ${ }^{182}$ By the mid-Twentieth Century, rabbis had begun to issue guidelines as to ingredients - which, at least in the United States, the ingredients had to be listed on every packaged food. ${ }^{183}$ At one point, it was satisfactory to check these lists to determine whether the product was kosher. ${ }^{184}$ For example, a product was not considered kosher if it contained "shortening," but was if it contained "vegetable shortening."185 As processors developed other additives, governmental standards evolved accordingly. ${ }^{186}$ In short order, the rabbinic guidelines changed, so that the key ingredient had to be "pure vegetable shortening," then " $100 \%$ pure vegetable shortening." 187

Such informal guidelines were gradually replaced by required symbols, the trademarks of kosher certification agencies, which made the kosher consumer's task much easier by assuring them that virtually all processed foods labeled as "kosher" could be bought with confidence that they truly abided by the Jewish dietary laws. ${ }^{188}$

As the complexity of manufacturing processes and the need for kosher certification increased, so have the number of agencies and individuals interested in meeting the need - especially in view of the fact that kosher food has become popular among non-Jews as well. ${ }^{189}$ The

182. Id. at 32. The Union of Orthodox Rabbis is also referred to as the Orthodox Union, throughout.

183. See Pure Food and Drug Act of 1906, Pub. L. No. 59-384, 34 Stat. 768, repealed by Federal Food Drug and Cosmetic Act, 21 U.S.C. $\$ 392$ (1938).

184. See The Kosher Primer, OU KosHer, http://oukosher.org/the-kosher-primer/ (last visited Dec. 10, 2014).

185. See id.

186. See id; EIDliTz, supra note 60 , at 1.

187. $I d$. The author was raised in a kosher household, and clearly remembers the progression in labeling. Ultimately some rabbis declared that even " $100 \%$ pure vegetable shortening" may contain non-kosher emulsifiers. Zushe Yosef Blech, Kosher Food Production 287 (2nd ed, 2008). See also Tzvi Rosen, Kashrus Goes Crunch, 35 Kashrus Kurrents 4 (Fall 2013), available at http://www.star-k.org/kashrus/kk-palate-crunch.htm (noting that even potato chips fried in pure vegetable shortening may have been cooked in non-kosher kettles).

188. EIDlTz, supra note 60 , at 1 ; see also RAKEFFET-RothKofF, supra note 109, at 147; Maayan Jaffe, The Kosher Machine, Baltimore Jewish Times, August 7, 2013, http://jewishtimes.com/9254/the-kosher-machine/2/.

189. See Karen Barrow, More People Choosing Kosher for Health, N.Y. Times, (April 13, 2010) http://well.blogs.nytimes.com/2010/04/13/more-people-choosing-kosher-for-health. The laws of kashrut would be binding on members of the Jewish faith regardless of whether or not it was indeed healthier. Whereas Maimonides subscribed the opinion that all non-kosher food was unwholesome many other leading rabbis disagreed, chief among them was Don Issac Abarvenel in his commentary on the bible to Leviticus chapter 11. Moses Maimonides, Guide for the PerPleXed 3:48 (M. Friedländer trans.,1904), available at http://www.sacred-texts.com/jud/gfp/ gfp184.htm; Don Isaac Abarbanel, Commentary Parshat Sh'mini, Leviticus 6:1 - 11:47, 
OU, the first to offer supervision and certification, now operates in all 50 states and 92 countries around the world, certifying hundreds of thousands of products and ingredients that kosher consumers have become accustomed to using daily. ${ }^{190}$ The OU remains the largest kosher agency, but others were quick to capitalize on the growing demand for kosher food - including the OK Laboratories, VHM, the KOF-K, and the Star K. ${ }^{191}$ Individual rabbis have also re-entered the kosher supervision business, often using their own symbols to certify a product's kashrut. ${ }^{192}$

This phenomenon has brought with it a good deal of confusion, to the point that determining which supervisor is involved and to what standards he adheres sometimes requires a good deal of detective work. ${ }^{193}$ The more Orthodox the modern consumer, the more likely he is to rely only on the better-known certifying agencies rather than take the risk that a product may not meet the strictest supervision. ${ }^{194}$

In the latter part of the Twentieth Century, statutory regulations have helped to ensure the authenticity of food labeled as kosher, as have the common-law fraud litigation that has ensued therefrom. ${ }^{195}$

Just as the production and processing of milk and meat has become big business, so has both private supervision and government regulation. It is not hard to see that, over the past century and a half, sweeping commercialization has become a prime mover of the boom in the kosher food industry. ${ }^{196}$ Another impetus has been the increasing number of consumers who view kosher food as a healthier choice. ${ }^{197}$ Regardless of the debate of the inherent wisdom of the Bible in regards to health benefits, many consumers seem to feel that the extra

RABBinical Assembly, available at http://www.rabbinicalassembly.org/sites/default/files/public/ resources-ideas/source-sheets/tol-parashot/sh-mini.pdf. Maimonides himself held that the health benefit of kashrut is not a reason to keep kosher but rather just a tangential benefit: "It is appropriate that one meditate, according to his intellectual capacity, regarding the laws of the torah to understand their deeper meaning. Those laws for which he finds no reason and knows no purpose should nevertheless not be treated lightly." Maimonides, Laws of ME'ILAH 8:8.

190. About OU Kosher, OU KoshER, http://oukosher.org/about-the-ou/ (last visited, Dec. 10, 2014).

191. EIDLITZ, supra note 60 , at 32.

192. See Id.; see also KosherQuest, supra note 27.

193. EIDLITZ, supra note 60 , at 32.

194. See KosherQuest, supra note 27.

195. See, e.g. Eidurrz, supra note 60, at 3.

196. See supra Part II.C. ("Kosher Slaughter").

197. Barrow, supra note 193; see also 3 in 5 Kosher Food Buyers Purchase for Food Quality, Not Religion, MinTEL, (Feb. 27, 2009), http://www.mintel.com/press-centre/press-releases/321/3in-5-kosher-food-buyers-purchase-for-food-quality-not-religion. 
set of eyes in the form of kashrut inspectors serves to ensure a cleaner product. ${ }^{198}$

This perception is largely due to the thorough process which kosher food undergoes. ${ }^{199}$ The preparation of meat, for example, requires multiple stages of salting to remove the blood from the flesh. ${ }^{200}$ Hindquarters and certain fats are forbidden and must be removed. ${ }^{201}$ This protocol of processing and exclusion are thought to reduce contamination of E. coli bacteria and diseases such as trichinosis - a disease usually found in pigs, one of the animals strictly prohibited by Jewish law. 202

There is also the growing Orthodox Jewish population, which strictly adheres to the Shulchan Aruch's codification of the laws of kashrut. ${ }^{203}$ Those rules fall into two general categories: the types of food that may be consumed, and how they must be processed.204 All pork and shellfish products are categorically forbidden, as are certain parts of otherwise kosher animals. ${ }^{205}$ It is likewise prohibited to eat meat and dairy products together. ${ }^{206}$

The rules governing food preparation are equally strict. The most important aspect of kosher meat preparation is the process of ritual slaughter, or shechita. ${ }^{207}$ Torah law requires that all animals and poultry be slaughtered in a very precise fashion; the regulations for shechita are complex and minute. ${ }^{208}$ Every step of the process emphasizes the traditional Jewish respect for the dignity of life. ${ }^{209}$ The animal's trachea and esophagus must be severed with a single swift stroke of the knife. ${ }^{210}$ Great care is taken to use a knife that has been properly sharpened: "[t]he blade must be flawless, without a nick, and

198. Barrow, supra note 193.

199. See, e.g. id.

200. Id.

201. $I d$.

202. Penne Cole, The Health Benefits of a Kosher Diet, Culinary Arts 360, (Aug. 6. 2009), http:/www.helium.com/items/1543396-health-benefits-of-kosher-food.

203. See, e.g. Josh Nathan-Kazis, Orthodox Population Grows Faster than First Figures in Pew \#JewishAmerica Study, JEwISH DAILy ForwARD, Nov. 12, 2013, http:/forward.com/articles/ 187429/orthodox-population-grows-faster-than-first-figure/?p=all.

204. See generally Shulchan Aruch, Yoreh De'ah, ch. 1-25, Torah.org (Dec. 10, 2014) http:// www.torah.org/advanced/shulchan-aruch/archives.html.

205. See supra Part II.A.

206. $I d$.

207. See e.g., OxFord, supra note 11, at 732-33 (2d. 2011) (defining "terefah", or non-kosher).

208. EiduITz, supra note 60 , at 76.

209. Id.

210. Id. at 77 . 
perfectly smooth," in order to assure that "the kill will be quick, clean and [virtually] painless to the animal."211

A trained and rabbinically licensed individual must carry out the actual slaughter. ${ }^{212}$ Afterwards the shochet must also carefully examine the organs; if he finds any imperfections, the entire animal is considered unclean and unfit for consumption.213

After soaking and salting, a kosher seal is either attached or stamped onto the meat or chicken. ${ }^{214}$ "A large slaughterhouse, when operating full time, may be able to slaughter 60 to 150 animals per hour."215 Even with all of these precautions, "[o]nly about 30 percent of animals" killed by shechita qualify for certification as kosher. ${ }^{216}$ That fact alone might cause significant problems in the marketplace, but as we shall see the kosher business is even more strongly influenced by greed, complacency, power, control - all of which have legal ramifications as well.

211. EIDLITZ, supra note 60 , at $76-77$.

212. See OxFORD, supra note 11, at 627 (2d. 2011) (defining "ritual slaughter").

213. Id. Shechita is comprised of five major elements:

a) there should be no interruption of the incision (Shehiya); b) there should be no pressing of the chalaf against the neck (Derasa), this would exclude use of an axe, hatchet or guillotine; c) the chalaf should not be covered by the hide of cattle, wool of sheep or feathers of birds (Chalada), and therefore the chalaf has to be of adequate length; d) the incision must be at the appropriate site to sever the major structures and vessels at the neck (Hagrama); e) there must be no tearing of the vessels before or during the shechita process (Ikkur).

A Guide to Shechita, SHECHITA UK (2009), shechitauk.org/fileadmin/user_upload/pdf/A_Guide_

to_Shechita_2009_.pdf.

214. EIDLITZ, supra note 60 , at $76-77$.

215. Id.

216. Id. Failure to comply with the five major elements of shechita could render them nonkosher. See A Guide to Shechita, supra note 217. In addition, there are eight types of mortal injury that render an animal non-kosher: when

(1) a poisonous substance [has been] introduced into the body by an animal of prey hacking with its claws; (2) an organ [has been] perforated; (3) complete organs or parts of them [are missing]; (4) organs or parts of them hav[e] been removed; (5) walls or covers of organs [are] torn; (6) [parts of the animal have been] shattered by a fall; (7) pipes [have been] split; or (8) [bones have been fractured].

EidLITZ, supra note 60 , at $78-79$. 


\title{
III. Sacred Cows: Legal Controversies over Regulating Meat AND Milk
}

\author{
"Where are you going, my pretty maid?" \\ "I'm going a-milking, sir," she said. \\ "Dear maiden, I'd like to disclose the fact, \\ That I'm an inspector under the Act. \\ So pray remain, for I want to know \\ A thing or two before you go."217
}

In Western society, law reaches into every stage of food preparation and delivery, from the production of milk to the slaughtering of livestock, from pasture to market. For example, American courts have ruled that kosher butchers may be excluded from collective bargaining units, ${ }^{218}$ that a Jewish court of arbitration panel may forbid trade with disapproved butchers, ${ }^{219}$ that retail sellers implicitly stipulate their compliance with rabbinic authorities, ${ }^{220}$ that a state law may incorporate a rabbinical ruling on kosher labeling, ${ }^{221}$ and that kosher symbols may be subject to trade infringement laws. ${ }^{222}$

Although courts do not attempt to interpret the complex laws of kashrut, which not only prescribe which animals are kosher but also mandate the requisite slaughter and preparation, they do abide by secular statutes that dictate humane treatment. ${ }^{223}$ Some secular statutes come into conflict with Jewish law, which strictly prohibits shooting the animal in the head with a bolt-gun prior to slitting its throat, for example. 224

217. "Inspector Under the Act," in HARvest, an ANThOlogy of FARM Writing (Wheeler McMillen ed., 1964) (1907), reprinted in Pasteurization, supra note 166. "The poem may have been written in reference to the Pure Food and Drug Act passed the year previous (1906)." Id. Because this is serious business to both consumer and regulator alike, the Author has chosen not to invoke a somewhat briefer ditty from Ogden Nash (American poet, 1902-1971), to wit: "The cow is of the bovine ilk; One end is moo, the other, milk." Quips \& Quotes: Ogden Nash, STORYRHYME.com (2008), http://www.storyrhyme.com/stories/rhymes_chimes/quips_quotes_ nash/.

218. See Aurora Packing Co. v. NLRB, 904 F.2d 73, 77 (D.C. Cir. 1990).

219. See S.S. \& B. Live Poultry Corp. v. Kashrut Ass'n of Greater N.Y., 285 N.Y.S. 879,891 (N.Y. Sup.Ct. 1936).

220. See Cohen v. Silver, 178 N.E. 508, 510 (Mass. 1931).

221. See People v. Gordon, 14 N.Y.S.2d 333 (Kings Cnty. Spec. Sess. 1939), rev'd, 16 N.Y.S.2d 833 (N.Y. App. Div. 1940), aff'dmem., 28 N.E.2d 717 (N.Y. 1940); see also Ran-Dav's Cnty. Kosher, Inc. v. State, 129 A.2d 141 (N.J. 1992).

222. See, e.g., Levy v. Kosher Overseers Ass'n of Am., Inc., 104 F.3d 38 (2d Cir. 1997).

223. See, e.g., Gordon, 14 N.Y.S.2d at 334.

224. A blow to the head may mortally wound the animal rendering it a "treif" (not kosher). See EIDLITZ, supra note 60, at 78-79 for a description of ways an animal can become non-kosher. Any animal suffering a mortal wound or injuries thought to be mortal wounds by the rabbis of 
From time to time various regulations have tried to prohibit ritual slaughter. The kosher food industry has successfully challenged any such regulations as an infringement on religious freedom - arguing that butchering is inherently gory but that kosher shechita is as, if not more, humane than the conventional methods.225 The Humane Slaughter Act, ${ }^{226}$ which has been upheld as constitutional under the First Amendment, specifically exempts ritual slaughter. ${ }^{227}$

Ritual slaughter has not always been exempted. Over the centuries, states, legislatures, and courts have challenged many of the religious dietary laws. ${ }^{228}$ Indeed, kosher wars are still being fought today on an international level, and ritual slaughter is forbidden in various other countries around the world - none of which have anything like American Constitutional prohibitions against mixing matters of church and state. ${ }^{229}$

Such bans are not new. In 1860, the Society for the Prevention of Cruelty to Animals in Switzerland halted shechita in that country by successfully lobbying the government "to require that all cattle be stunned before slaughter."230 In 1894, the Swiss Constitution was amended to read, " $[t]$ he slaughter of animals without prior stunning before the withdrawal of blood is prohibited without exception for every type of slaughter and every species of animal."231 By the time World War II broke out, the importing of kosher meat had become impossible. ${ }^{232}$ The local board of rabbis petitioned the Swiss government for a temporary stay of the ban. ${ }^{233}$ The government responded

the Talmud would render the animal unfit for consumption. Id.; see also Forst, supra note 12, at 37.

225. See Jones v. Butz, 374 F. Supp. 1284 (S.D.N.Y. 1974) affd, 319 U.S. 806 (1974); see also, e.g., Shechita-The Jewish Ritual Slaughter of Animals, MicaH PubL'Ns., INC., http://micahbooks .com/shechita-the-jewish-ritual-slaughter-of-animals-34.html (last visited March 7, 2013).

226. 7 U.S.C. $\$ 1901$ (2006).

227. See Butz, 374 F. Supp. 1284 (S.D.N.Y. 1974), aff'd, 319 U.S. 806 (1974); see also Church of LukumiBabalu Aye v. City of Hialeah, 508 U.S. 520 (1993). See Gerald F. Masoudi, Kosher Food Regulation and the Religion Clauses of the First Amendment, 60 U. CHI. L. Rev. 667 (1993), for a discussion regarding the interaction of state statutes and kosher regulations.

228. See Moshe Schuchman, A Cut Above: Shechita in the Crosshairs, Again, 33 Kashrus Kurrenrs 4 (2012), available at http://www.star-k.org/kashrus/kk-ACutAbove.

229. See generally, id.

230. Id. at 4

231. The Ban on Shechita in Switzerland, Schwiezericher ISRAELITISCHER GemeINDEbUND, http:/www.swissjews.ch/en/religioeses/koscherfleisch/schaechtverbot.php (last visited Mar. 6, 2013).

232. See Ronit Gurtman, Shehitah: Jewish Ritual Slaughter 25 (Apr. 2005) (unpublished Third Year Paper, Harvard Law School), available at http://nrs.harvward.edu/urn-3:HUL.InstRepos:88 52091.

233. Id. at 27. 
that it would allow animals to be drugged before slaughter. ${ }^{234}$ The rabbis debated this proposal at length before finally deciding that the process would not satisfy kashrut standards. ${ }^{235}$ In the mid-Twentieth Century, Swiss legislators briefly considered rescinding the religious articles of the national constitution, but they were adopted in their entirety and eventually incorporated into the Animal Protection Act of 1978 - which remains the law in Switzerland today. 236

Whether the Swiss restriction on kosher slaughtering was anti-Semitic in nature is still widely argued, but there is little such uncertainty in Germany, where shechita was outlawed in 1933 as part of the infamous Nuremberg Laws. ${ }^{237}$ The Allied Command removed the prohibition when Europe was liberated in 1945.238 Norway banned religious slaughter without pre-stunning in 1930.239 Sweden did the same in 1937.240

Norway is another modern nation to prohibit the production of kosher meat, even though it permitted halal and encourage the slaughter of "seals, wales and other animals that are protected by international treaties." The issue of animal cruelty was raised as early as the 1890 s, but the Norwegian Jewish community successfully argued that the shechita method of slaughter was humane. ${ }^{241}$ The debate continued well after the turn of the Twentieth century. In 1927, a parliamentary agriculture committee, after "consult[ing] numerous experts and visiting a slaughterhouse in Copenhagen," recommended a permanent ban

234. Id. at $27-28$.

235. Id. This arrangement was first approved by the Rabbinical Assembly, but never became effective. $I d$.

236. See The Ban on Shechita in Switzerland, supra note 235; see also Schuchman, supra note 232.

237. See Gurtman, supra note 236 , at 28 . In 2002 , the German Constitutional court allowed Muslims an exception for ritual slaughter. Id. at 41 . "Section $4 \mathrm{a}(2)(2)$ of the Tierschutzgesetz provides for an exception from this rule for religious associations that (1) require ritual slaughter, or (2) prohibit the consumption of meat that is not halal, that is, that does not come from animals slaughtered in accordance with their religious prescriptions." Id. (citation omitted). The 2002 exception to religious slaughter came to remedy a larger problem. In 1995, the German Muslims were prohibited from performing halal slaughter. Id. at 42 . A federal court held that there was no mandatory need for Islamic slaughter; thereby, failing the second prong of section 4a of the Tierschutzgesetz. Id. The Court held that its ruling was not a "violat[ion] of the right to religious freedom guaranteed by articles 4(1) and (2) of the Basic Law" because Muslims could still eat fish. Id. Additionally, the court favoring one opinion in disagreement among Islamic scholars held that kosher meat was acceptable in lieu of halal meat. See Id.

238. Isaac Lewin, et al., Religious Freedom: The Right to Practice Shehitah 212-13 (1946)

239. Id. at 79 .

240. Id. at 82.

241. Kosher Food \& Shechita Controversy in Norway, Kosher Delight (Oct. 22, 2012), http://www.kosherdelight.com/Norway_Kosher_Food.shtml [hereinafter Kosher Food]. 
on shechita. ${ }^{242}$ In 1929, the Norwegian Parliament banned the slaughter of animals that had not first been stunned or paralyzed. ${ }^{243}$

Representatives of both Norway's Muslim and Jewish communities cited scientific studies to dispute the claim that halal and shechita caused unnecessary animal suffering. ${ }^{244}$ They also raised the country's acceptance of hunting, whaling, and sealing to demonstrate the hypocrisy of its policy. ${ }^{245}$ But, the Norwegian Food Safety Authority stuck by its position that animals subjected to shechita were conscious for "several minutes" after they were slaughtered. ${ }^{246}$ One critic declared that animals in Judaism had "no moral status" and were "pure objects for . . . archaic, religious needs." 247 The "[prohibition] remains in force today." 248

The experience in Poland is of special significance because of that country's history during the Holocaust. Poland actually "began legislating against kosher slaughter in 1936." 249 Over the next three years, "[m]ore than 90 percent of Poland's 3.5 million Jews were killed." 250 After the Nazis invaded the country in the fall of 1939, "the practice was banned entirely."251 "Since the fall of the communist regime in 1989 , however, ... [f]ull recognition of the rights of Jews to practice their faith, including kosher slaughter, [came into being,] and was enshrined in an agreement the government signed with the Jewish community in 2004."252

But in January of 2013, a Polish court ruled that Jews could not be exempted from legislation mandating the use of electronic stunning equipment before an animal is killed (a practice prohibited by Jewish law). ${ }^{253}$ " [T] $\mathrm{T}$ his was viewed as a major victory for animal rights advocates, as their views prevailed against the nation's farmers and meatpackers, who had developed a lively business exporting kosher and halal meat to Israel and Muslim countries."254

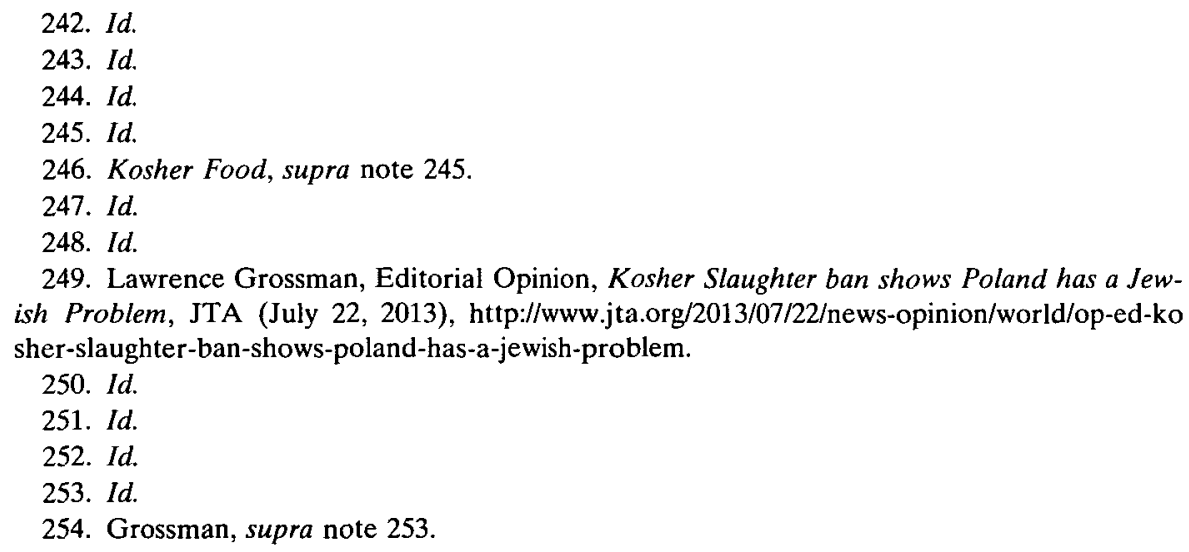


The fact that many Western nations still permit shechita does not necessarily mean they consider the practice humane. Most countries choose simply to exempt ritual slaughter from the law rather than attest to it being humane. ${ }^{255}$ A notable exception to this rule is Great Britain, which continues to abide by a 1925 House of Commons report that found shechita to be "practically and physiologically the best method" of slaughter. ${ }^{256}$ In fact, the scientific evidence supports this finding. ${ }^{257}$ Several early studies found that the toxicity levels in the blood of animals slaughtered according to the Biblical rules of shechita were considerably less than in those who were not. ${ }^{258}$ Religious slaughter in England has not changed to this day. ${ }^{259}$

\section{A. Statutory Regulation of Kosher Fraud}

The misrepresentation of non-kosher food as kosher, whether or not intentional, has probably existed for as long as the dietary laws have been around. Likewise, "kosher fraud in America is nearly as old as the nation itself." 260 The "financial incentive to commit kosher fraud" rests primarily in the fact that false labeling allows the purveyor to increase profits because certification can be expensive. ${ }^{261}$ During the Eighteenth Century, the Shearith Israel Congregation in New York employed the city's only slaughterer of kosher meat.262 The Congregation profited from shipping its kosher meat, accompanied by certificates and labeled with the Congregation's seal, through-

255. See, e.g., Butz, 374 F. Supp. 1284 (S.D.N.Y. 1974).

256. Gurtman, supra note 236, at 43.

257. See, e.g., David I. Macht \& Helen M. Cook, Toxicity of Muscle Extracts After Arteriotomy, Asphyxiation, Injuries to the Brain and Electrocution, 97 AM. J. PHYsiologr 602, 664 (1931) [hereinafter Macht]; David I. Macht \& Mary E. Davis, Quantitative Comparison of Some Muscle and Nerve Reactions after Decerebration and Decapitation, 102 AM. J. PHYsiology 138, 138 (1932) [hereinafter Quantitative Comparison]; see generally I.M. Levinger, Physiological and General Medical Aspects of Shechita, in Shechita: Religious Historical and Scientific ASPECTS 99, 192-95 (Philipp Feldheim Inc. 1976).

258. See Macht, supra note 261, at 664; Quantitative Comparison, supra note 261, at 138.

259. See Gurtman, supra note 236, at 44. The Welfare of Animals (Slaughter or Killing) Regulations, 1995, 1995 No. 731 , c.22, sch.12, available at http://www.legislation.gov.uk/uksi/1995/731/ contents/made. The 2012 amendments to the regulation did not change religious slaughter exemptions. See Slaughter of Livestock: Welfare Regulations, Gov.uk (Aug. 29, 2012), https://www .gov.uk/farm-animal-welfare-at-slaughter.

260. Shayna M. Sigman, Kosher without Law: The Role of Nonlegal Sanctions in Overcoming Fruad within the Kosher Food industry, 31 FLA. ST. U. L. Rev. 509, 536 (2009)

261. See id. at 545.

262. Jeremiah J. Berman, Shehita: A Study in the Cultural and Social Life of the Jewish People 275 (1941). The estimated Jewish population was 1000 to 3000 people during the Revolutionary Era. American Jewish Desk Reference: The Ultimate One-Volume RefERenCE to the Jewish EXPerience in AMerica 35 (1999). 
out the Americas. ${ }^{263}$ In 1796 and 1805, two unscrupulous "meat vendors were found to have affixed" the Congregation's seal on meat that was not kosher. ${ }^{264}$ As early as 1885, "rabbinic organizations began to affix a unique label to foods the organization certified as kosher."265 For more than a century thereafter, many states and local jurisdictions passed laws regulating the use of the term "kosher" in the food industry. ${ }^{266}$

The fraudulent sale of non-kosher food as kosher is not easily detectable by the average consumer seeking to observe the dietary laws. ${ }^{267}$ It is even more difficult to prove that the sale or substitution of a non-kosher item was an intentional act. ${ }^{268}$ But victims of kosher fraud do have recourse in the courts. ${ }^{269}$ They can sue alleged violators at common law, in either contract - "the kashrut of the food was a material [part] of the sale" - or tort - "misrepresentation of a material fact." 270 Consumers who win damage awards can be reimbursed for "medical costs and compensate[d] for pain and suffering."271

Once caught, perpetrators of a kosher fraud - as opposed to those who have made an honest mistake - seldom if ever are allowed to remain in business. 272 They are likely to be decertified immediately and thus lose whatever reputation they may have once enjoyed among kosher consumers. ${ }^{273}$

It was not until after substantial Jewish immigration and technological advances in the food industry that kosher fraud became an increasing problem. ${ }^{274}$ The $\mathrm{OU}$ was a primary actor in the campaign to enact the kosher fraud statutes. 275

In 1915, New York enacted the first kosher fraud statute in the United States, the primary purpose and effect of which was to prohibit falsely advertising non-kosher food as kosher. ${ }^{276}$ The legislation con-

263. BERMAN, supra note 266 , at 280 .

264. Id. at 284.

265. Mark Popovsky, The Constitutional Complexity of Kosher Food Laws, 44 Colum. J.L. \& Soc. Probs. 75,

266. Sigman, supra note 264 , at 512 . Most such laws in force today, however, if subjected to strict-scrutiny review, would likely be found unconstitutional. See id. at 551-58.

267. Sigman, supra note 264 , at 525 .

268. Id. at 558 .

269. $I d$. at 548 .

270. Id.

271. Id; see Restatement (Second) of Contracts $\$ 347$ (1981); Restatement (Third) of Torts: Products Liability $\S 9$ (1998).

272. Sigman, supra note 264 , at 547.

273. See id.

274. Id. at 552.

275. Id.; see also GASTWIRT, supra note 107, at 98, 125-127.

276. Popovsky, supra note 269 , at 83 . 
tained a series of provisions dictating what standards must be met in order to legally advertise packaged food or food establishments as kosher. ${ }^{277}$

277. Id. (quoting N.Y. Penal Law $\$ 435(4)$, Laws of 1915 , c. 233). The statute sought to penalize any

person who with intent to defraud ... sells or exposes for sale any meat or meat preparation and falsely represents the same to be kosher, or as having been prepared under and of a product or products sanctioned by the orthodox Hebrew religious requirements; or falsely represents any food product or the contents of any package or container to be so constituted and prepared, by having or permitting to be inscribed thereon ... "kosher" in any language is guilty of a misdemeanor.

Id.; see also Stephen F. Rosenthal, Food For Thought: Kosher Fraud Laws and the Religion Clauses of the First Amendment, 65 GEO. WASH. L. Rev. 951, 956 (1997) (discussing the history of kosher fraud laws). These provisions no longer appear in the Penal Law, but are now contained in the kosher-fraud statutes detailed below. See NY Agri. \& MkTs. Ch. 69, Art. 17. Violation of the New York statute constituted a misdemeanor. Id.

A brief summary of its pertinent provisions:

Article 17 of New York State's Agriculture and Markets Law is entitled "Adulteration, Packing, and Branding of Food and Food Products." Id. Section 201-a therein provides that a "person who, with intent to defraud, sells ... any meat ... and falsely represents [it] ... as having been prepared under . . the orthodox Hebrew religious requirements . . . is guilty of a class ' $A$ ' misdemeanor." Id. at § 201-a. "Section 201-b(1) is identical to section 201-a except it applies to sale of food in hotels and restaurants." Elizabeth M. Williams \& Stephanie J Carter, The A-Z EnCyClopedia of Food Controversies and the LaW 432 (2011). Section 201-c(1) prohibits willfully marking food as "having been prepared in accordance with the Hebrew orthodox religious requirements" if in fact it was not prepared in that manner. Art. 17 at $\S 201-c(1)$. Section 201-c(2) forbids defacement or alteration of labels to indicate that they are "kosher or have been prepared in accordance with the Hebrew orthodox religious requirements" when the food is not actually kosher. Id. at $\$ 201-\mathrm{c}(2)$. Section 201-c(3) makes illegal the "sale, possession, or disposal of (1) any food product without its original slaughterhouse label, or [of] (2) any food product to which such label has been fraudulently affixed. Williams, supra note 281 , at 433.

Section 201-e(2a) mandates that if "non-prepackaged fresh meat or poultry is sold and delivered off-premises as Kosher, the meat or poultry and the bill of sale ... rendered at the time of delivery shall have affixed a label or the printed words 'not soaked and salted' or 'soaked and salted." Id. at $\S 201-\mathrm{e}(2-\mathrm{a})$. Section 201-e(3-c) "requires slaughterhouses that sell kosher food products to maintain records 'regarding the time, place, date, person or organization supervising the slaughter of $\ldots$ and the number of animals slaughtered in accordance with orthodox Hebrew religious requirements." WILLIAMS, supra note 281, at 433 (quoting Art. 17 at $\$ 201-\mathrm{e}(3-)$ )).

Section 201-f-(1) provides that "all meat or poultry . . represented as having been prepared in accordance with orthodox Hebrew religious requirements, [but] which has not been soaked and salted immediately after slaughter [ ]," must have a tag affixed to it "stating the date and time of day ... of slaughter," and must be "washed in accordance with orthodox Hebrew religious requirements within seventy-two hours after slaughter." Art. 17 at $\S 201-f(1)(a),(b)$. Subsection (2) dictates that "[n]o person shall sell . . . any meat or poultry which is represented as having been prepared in accordance with orthodox Hebrew religious requirements, unless it conforms to the requirements [of subsection one]." Id. at $\$ 201-\mathrm{f}(2)$.

Section $201-\mathrm{h}$ prohibits "label[ing] food with the word[ ] pareve . . or in any way indicating that the food may be ... consumed indiscriminately with meat, poultry or dairy products according to Orthodox-Hebrew requirements when such food is not permissible for such . . . consumption." WILLIAMs, supra note 281, at 433 (quoting Art. 17 § 201-h)). 
Since the passage of the New York statute, twenty-one other states have enacted similar legislation. ${ }^{278}$ Other states have "deceptive business trade acts that prohibit false advertising and misrepresentation," which might be applied to the sale of non-kosher food advertised as kosher. ${ }^{279}$

Most kosher fraud statutes are written in a similar fashion: they define what kosher means, identify the intent required for committing kosher fraud, and provide for an enforcement mechanism. ${ }^{280}$ Nearly all such laws define kosher in reference to "the orthodox Hebrew religious requirements" or those "sanctioned by the Code of Jewish Laws." 281 In addition, there must be evidence of a "specific intent to defraud, or knowledge [of the misrepresentation]." 282

The authority to inspect whether food retailers are complying with the law is vested variously in the "attorney general, a state commission or special agency," or with local rabbis. ${ }^{283}$ The penalty for violating the statutes vary from state to state; most allow for the imposition of fines, but some even provide for imprisonment. ${ }^{284}$

Finally, "section 26-a(4), establishes a nine-person advisory board on kosher law enforcement ... to advise on . . . policy in connection with the administration and enforcement of [kosher fraud laws]." WILliaMs, supra note 281 , at 434.

278. Sigman, supra note 264 , at 551 .

279. Id. at 550. See also "A Meaty Question," Tне Economist (Feb. 9, 2013), http://www .economist.com/news/international/21571419-who-should-regulate-kosher-and-halal-foodmeaty-question.

280. See Sigman, supra note 264 , at 551-53 (citing, among others, Wis. STAT. AnN. $\$ 97.56(2)$ (c) (West 2012) (prohibiting the sale of both kosher and non-kosher food unless there are signs stating, "in block letters at least 4 inches in height, 'Kosher and Non-kosher Meat Sold Here" ") and N.J. STAT. ANN. \& 2C:21-7.4 (c)(1) (West 2013) (A person commits a disorderly persons offense if while conducting business he "sells, offers for sale, prepares, or serves in or from the same place of business both unpackaged non-kosher food and unpackaged food he represents to be kosher unless he posts a window sign at the entrance of his establishment which states in block letters at least four inches in height: 'Kosher and Non-Kosher Foods Sold Here,' or 'Kosher and Non-Kosher Foods Served Here,' or a statement of similar import.")).

281. See id. at 553.

282. Id. "Many of the statutes not only prohibit non-kosher food falsely represented to be kosher" but also require that the name and address of the [local kosher supervisory agency be registered, and that signs be posted "differentiating between kosher and non-kosher meat" where both are sold. Id.

283. Id.

284. See id. at 554 (citing 410 Ill. Comp. Stat. AnN. 645/2 (West 2003) (stating violation of the act constitutes either a Class C or a Class A misdemeanor); ARK. CodE ANN. \$ 20-57-401(3) (West 2003) (stating that a violator "is guilty of a misdemeanor and punishable by a fine of not more than five hundred dollars $(\$ 500)$ or by imprisonment of not less than thirty (30) days or not more than six (6) months"); MAss. GeN. Laws ANN. ch. 94, § 156(h) (West 2003) (requiring a "civil penalty or fine of not less than five hundred dollars and not more than two thousand dollars")). 
Today, "the U.S. Department of Agriculture (USDA) is responsible for overseeing all [American] slaughter operations." 285 It employs "7,500 inspectors throughout the country."286 "[W]ithout a USDA stamp, meat cannot leave a slaughterhouse."287 In recent years, "a consensus has grown that the USDA's regimen of visual, carcass-bycarcass inspection - enshrined by the 1906 [Act] - places too much manpower on the kill[ing] floor and not enough in [testing laboratories] and meat-grinding plants to test beef for $E$. coli, poultry for Campylobacter, and pork for Toxoplasma."288 "Splash enough chemicals on," said one meat inspector, "and you can call anything safe."289

\section{B. Kashrut and the Courts}

As might be expected, the constitutionality of the so-called "Kosher Fraud" statutes and laws has been challenged in subsequent litigation. ${ }^{290}$ Among the questions that quickly came to the fore: Does the concept of regulating kosher meat impermissibly entangle church and state functions? Does such legislation violate sound public policy by granting state subsidies to private kosher consumers?

The first case to challenge the constitutionality of a kosher fraud statute happened in 1916, People v. Goldberger. ${ }^{291}$ There, "two purveyors of kosher foodstuffs who had been prosecuted under the New York kosher food law ... argued that the term 'kosher' in the statute was foreign and unintelligible and thus unconstitutionally [vague];" that the law violated the Equal Protection clause of the Fourteenth Amendment because it "specifically targeted one class of citizens;" and that by "codify[ing] religious doctrine into state law," the statute offended the New York Constitution by "establishing a state religion." 292

"Holding that the term kosher was sufficiently comprehensible," the court dismissed the appeal:

[T] he word "kosher," by extensive use, by its recognition by lexicographers of established authority ... must be recognized as an En-

285. Ted Conover, The Way of All Flesh, Harper's Magazine 35 (May 2013).

286. Id.

287. Id.

288. Id.

289. Id. (internal quotation marks omitted). "In 2011, President Obama signed the Food Safety Modernization Act[,] . . . a cooperative effort between the USDA's Food Safety and Inspection Service (FSIS) and the poultry industry [that] has set the stage for vast reductions in the number of on-site inspectors." Id. See Kenneth Lasson, Private Lives of Public SerVANTS 3-41 (Indiana University Press, 1978) for a depiction of the life of an investigator.

290. See, e.g., People v. Goldberger. 163 N.Y.S. 663 (Sp.Sess. 1916).

291. 168 N.Y.S at 663 ; Popovsky, supra note 269 , at 84.

292. Popovsky, supra note 269 , at $84-85$ (analyzing Goldberger, 168 N.Y.S. at 665 ). 
glish word; but, whether it is English or foreign, the Legislature in its plenary power has authority to deal with the subject matter, and that authority carries with it the power to use effectively the word that describes it, no matter whence derived. . . . [The statute is] a general regulation affecting all inhabitants of the state who may at any time be included within the class to which its provisions apply. ${ }^{293}$

"The court responded to appellants' [establishment claim] by [viewing] the statute as one promoting the free exercise of religion, a right that had been [stifled] by widespread fraud in the kosher food industry."294 "Since the statute ... promot[ed] free exercise, it avoided any establishment concerns."295

In a similar case two years later, People v. Atlas, 296 "another [purveyor] prosecuted under the New York kosher food law" argued that the term "kosher" was inherently unclear because it reflected "centuries of rabbinic debate[ and disagreements]," and that different Jewish communities interpreted the word differently. ${ }^{297}$ But, the New York Court of Appeals ruled "the state legislature intended to use the term 'in the ordinary sense in which it is used in the trade, which is to designate meat as having been prepared under and of a product sanctioned by [Orthodox Jewish] religious requirements." "298 "The term, [said the court], ha[d] a trade-specific definition not dependent on Jewish law," and was thus "sufficiently well defined to be constitutionally valid." 299

The Supreme Court first entered the fray in 1925, in Hygrade Provision Co. v. Sherman, ${ }^{300}$ in 1925 . There, too, the argument was not based on the religion clauses of the First Amendment, but rather that the term "kosher" as used in the New York statute was impermissibly vague in violation of the Due Process Clause of the Fourteenth Amendment. ${ }^{301}$ The Supreme Court likewise disagreed, thereby upholding the state's kosher fraud statute. ${ }^{302}$

293. Id. at 85 .

294. Id.

295. Id.

296. 170 N.Y.S. 834 (N.Y. App. Div. 1918), aff'd, 130 N.E. 921 (N.Y. 1921).

297. Popovsky, supra note 269 , at 86 (analyzing Atlas, 170 N.Y.S. at 835 ).

298. Id. (quoting Atlas, 170 N.Y.S. at 835-56).

299. Id. (citing Atlas, 170 N.Y.S. at $835-36$ ).

300. Hygrade Provision Co. v. Sherman, 266 U.S. 497 (1925).

301. Hygrade, 266 U.S. at 498, 501-02.

302. Id. at 503. See also Jones v. Butz, 374 F. Supp. 1284 (S.D.N.Y. 1974) (challenging the Humane Slaughter Act, 7 U.S.C. $\$ 1901$ (1970), particularly provisions relating to ritual slaughter); Sossin Sys., Inc. v. City of Miami Beach, 262 So. 2d 28, 29-30 (Fla. Dist. Ct. App. 1972) ("We are unable to view this ordinance as a legislative enactment establishing or respecting the establishment of a religion, or as one prohibiting the free exercise of religion to which is has 
In late 1987, a Jewish employee contacted the OU with a tip that Shelat Kosher Foods of Chicago, one of its clients and among the nation's largest suppliers of kosher chicken, was packaging and selling non-kosher food items. ${ }^{303}$ A surprise inspection verified the charge. ${ }^{304}$ Kosher consumers in as many as twenty-two states were affected by the fraud. ${ }^{305}$ An OU supervisor said that an incident of this magnitude had "never happened before in certification history." 306

The Illinois Consumer Protection Division, explaining why the case was not brought under the kosher fraud statute, stated that it "doubted the constitutionality of the [statute]" but "did not want to ... expend . . . resources litigating [the meaning of 'kosher.' "] ${ }^{307}$

The Illinois Attorney General's office, estimating that the processor "made about $\$ 250,000$ in profits" from its fraud, "sought both a permanent injunction against the [processor] as well as a large fine." 308 In November of 1987, the Cook County Circuit Court ordered that the Shelat plant be shut down and a "nationwide recall be conducted of more than 375,000 pounds of meat and poultry," and levied $\$ 250,000$ in restitution and fines against the company. ${ }^{309}$ "Shelat entered into a consent decree [in which it acknowledged fault] and agreed not to sell kosher food products." 310 In addition, the company was ordered to pay restitution and civil penalties. ${ }^{311}$

In 1990, in Ran-Dav's County Kosher, Inc. v. State, a supermarket charged with violating New Jersey consumer protection regulations claimed that New Jersey violated the Religion Clauses of the First Amendment. ${ }^{312}$ On appeal, the New Jersey Supreme Court applied the three-prong test presented by the U.S. Supreme Court in Lemon

reference."); Erlich v. Beverly Hills Judicial Dist. Mun. Ct., 360 P.2d 334 (Cal. 1961) (upholding the California kosher fraud statute against a void for vagueness challenge).

303. Sigman, supra note 264, at 568; see also MaryAnn Galante, Suit Says Shelat Falsely Labeled Foods Kosher, L.A. Times, (Nov. 6, 1987), http://articles.latimes.com/1987-11-06/businesses/fi-12838_1_kosher-chicken-products; William C. Hidlay, Companies Accused in Kosher Fraud Agree to Settlement, Associated Press, Feb. 26, 1988, http://www.apnewsarchive.com/ 1988/Companies-Accused-In-Kosher-Fraud-Agree-To-Settlement/id-17a7f5e5127e79cc5dac8dc5f 0ab1148.

304. Sigman, supra note 264 , at 568 .

305 . Hidley, supra note 307.

306. Galante, supra note 306.

307. Sigman, supra note 264 , at 569 .

308. Id.

309. Id.

310. Id.

311. Id.

312. Ran-Dav's County Kosher, Inc. v. State, 579 A.2d 316, 324 (N.J. Super. Ct. App. Div. 1990) 
v. Kurtzman. ${ }^{313}$ In order for a statute to be deemed constitutional, it "must have a secular legislative purpose; second, its principal or primary effect must be one that neither advances nor inhibits religion; [and] finally, the statute must not result in an excessive government entanglement with religion." ${ }^{314}$

The court noted that under Lemon's secular purpose test, a statute would fail only if "there is "no question that the statute or activity was motivated wholly by religious considerations." 315 As to the State's contention that the statute's purpose was to prevent consumer fraud, the court found that the mention of Orthodox doctrine was "unavoidably religious in character." 316 Under Lemon's second prong, whether the state gives the appearance of favoring or advancing one religion or denomination, the court held that the law was based on religious tenets and acted "both as a constraint and as an inducement on merchants who must abide by them[.]" 317

The court said that because the regulations "provide both substantive standards prescribing religious practices and procedures for their enforcement," the facts could be appropriately analyzed under Lemon's excessive-entanglement prong. ${ }^{318}$ The State argued that the term "kosher" assumed a secular connotation indicating a more sanitary and healthy product. ${ }^{319}$ The court rejected that argument, finding that the statute mandated "strict compliance with the laws and customs of the Orthodox Jewish religion," and noting that enforcement of the statute by a panel of ten rabbis (nine Orthodox and one Conservative) "underscore[d] the theological or religious nature of the State's regulatory endeavors." 320 In short, the court held the fraud statute to be excessive government entanglement. ${ }^{321}$

In 1995, an interesting case involving the sale of over-the-counter hot-dogs arose in Baltimore, home to a diverse population that in-

313. Id. at 176 .

314. Ran-Dav's, at 1358-59 (citing Lemon, 403 U.S. at 612-13). In so doing, the court avoided a strict-scrutiny standard for " explicit and deliberate distinctions between different religious organizations,' . . because the record suggest[ed] uncertainty concerning both the precise meaning and the enforcement standards of the regulations." Ran-Dav's, 608 A.2d at 1359 (quoting Larson v. Valente, 456 U.S. 228, 246 (1982)).

315. Id. at 1365 (citation omitted).

316. Id. at 1366 .

317. Id. at 1364.

318. Id. at 1359.

319. Ran-Dav's, 608 A.2d at $1356,1365$.

320. Id. at 1360-61 (citation omitted). See also Popovsky, supra note 269, at 107.

321. Ran-Dav's, 608 A.2d at 1355. 
cludes over 90,000 Jews, more than a third of whom consider themselves Orthodox or at least observant of the dietary laws. ${ }^{322}$

George Barghout owned a fast-food business called "Yogurt Plus," which sold both kosher and non-kosher foods. ${ }^{323}$ In 1983, the Baltimore City Council enacted an ordinance that made it a misdemeanor to offer for sale any food labeled kosher "with intent to defraud," or to indicate compliance "with the orthodox Hebrew religious rules and requirements and/or dietary laws" when the food does not in fact comply with those laws. ${ }^{324}$ "To aid in its enforcement, the ordinance create[d] a .. . Bureau of Kosher Meat and Food Control," which was composed of "three duly ordained Orthodox Rabbis and three laymen" selected by the mayor from "a list submitted by the Council of Orthodox Rabbis of Baltimore and the Orthodox Jewish Council of Baltimore." 325 The Bureau was charged with inspecting kosher food establishments in order to enforce the laws relating to sale of kosher meat to ensure compliance with the orthodox Hebrew religious rules and requirements. Though members of the Bureau were not paid, they were authorized to employ an inspector to report violators to law enforcement authorities. ${ }^{326}$

In September of 1989, the Bureau's inspector investigated a complaint that Barghout was violating the ordinance by "plac[ing] kosher hot dogs on a rotisserie next to non-kosher hot dogs," which allowed grease from both of the hotdogs to mix and thereby render the kosher hot dogs non-kosher. ${ }^{327}$ The Bureau issued a violation warning, which the owner refused to sign. ${ }^{328}$ Barghout challenged the Baltimore ordinance as a violation of the Establishment Clause. ${ }^{329}$ In Barghout $v$. Bureau of Kosher Meat \& Food Control, the Fourth Circuit struck down the law as facially unconstitutional, finding that "it fosters excessive entanglement of religious and secular authority by vesting significant investigative, interpretive, and enforcement power in a group of individuals based on their membership in a specific religious sect." 330

322. Laura Vozzella, Survey finds Growing Jewish Community, Less Engaged Youth, THE BALTIMORE Sun (Jan. 16, 2011), http://articles.baltimoresun.com/2011-01-16/news/bs-md-jewishcommunity-study-20110116_1_jewish-households-jewish-population-jewish-organizations.

323. Barghout v. Bureau of Kosher Meat \& Food Control, 833 F. Supp. 540 (D. Md. 1993), vacated on other grounds, 856 F. Supp. 250 (D. Md. 1994), af'd sub nom, 66 F.3d 1337 (4th Cir. 1995); see also Popovsky, supra note 269, at 90.

324. Barghout, 66 F.3d at 1338; Baltimore City Code art. 19, §§ 49-52 (1983).

325. Barghout, 66 F.3d at 1339.

326. Id.

327. Id.; Popovsky, supra note 269 , at 90.

328. Barghout, 66 F.3d at 1339.

329. Id; Popovsky, supra note 269, at 90.

330. Barghout, 66 F.3d at 1342. 
The Barghout court took issue with the fact that secular authorities were relying on members of the Orthodox Jewish faith to determine compliance with the ordinance. ${ }^{331}$ In so doing, it relied on earlier cases that "[made it] clear that a legislature [can neither] expressly delegate governmental functions to the governing body of a church [nor otherwise make] reference to doctrinal adherence." ${ }^{332}$ It is this "fusion of governmental and religious functions [whereby] a state ... delegate[s] its civic authority to a group chosen according to a religious criterion[ ]" that violates the Establishment Clause. ${ }^{333}$ Even the appearance of a joint exercise of authority between religious and secular authorities, according to Barghout, would create "a symbolic benefit for the religious sect, in this case Orthodox Judaism."334

Contributing to this impression was the fact that Baltimore's kosher food ordinance was codified under a separate section entitled "Kosher Meat," devoted exclusively to fraud in the sale of kosher food products. ${ }^{335}$ "No other particular type of consumer fraud is [similarly] singled out for separate treatment." 336 The court held that

Although the city council may have had a valid secular purpose for the ordinance, the fact that consumer fraud in the sale of kosher food is treated separately, more comprehensively, and is given its own enforcement mechanism, ... [shows] the primary effect of the ordinance is the advancement and endorsement of the Jewish faith, and in particular the Orthodox Jewish faith. ${ }^{337}$

An even more significant challenge to the constitutionality of kosher-fraud statutes came in 2002 in Commack Self-Service Kosher Meats, Inc. v. Weiss. ${ }^{338}$ At issue was whether, "by defining 'kosher' to mean food that is 'prepared in accordance with the orthodox Hebrew religious requirements," a New York statute violated the Establishment Clause of the First Amendment. ${ }^{339}$ The plaintiffs in Commack had obtained private supervision and certification from a Conservative rabbi, who asserted that the procedures the State alleged to be violations of the statute (some technical rules of soaking and salting

331. Id. at 1340 .

332. Barghout, 66. F.3d at 1343 (citations omitted) (internal quotation marks omitted).

333. Id. (citations omitted) (internal quotation marks omitted).

334. Id. at 1345 (quoting Larkin v. Grendel's Den, Inc., 459 U.S. 116, 125 (1982)).

335. Id. at 1346; see also Baltimore City Code art. 19, $\S \S 49-52$ (1983).

336. Id.

337. Barghout, 66. F.3d at 1346 .

338. 294 F.3d 415 (2nd Cir. 2002).

339. Commack, 294 F.3d at 418 . "Congress shall make no law respecting an establishment of religion. ..." U.S. Const. amend I. 
meat) were permissible under Jewish law. ${ }^{340}$ The problem is that not all Orthodox Jews follow the same standards. ${ }^{341}$

The Second Circuit Court of Appeals applied the Lemon test. ${ }^{342}$ Neither of the parties disputed that the laws were "enacted for the secular purpose of protecting consumers from fraud in the kosher food market." 343 However, the court found that the New York statute did serve to inhibit religion by preferring dietary restrictions of Orthodox Judaism over those of other branches of the faith: "by defining kosher according to the Orthodox view, the challenged laws 'symbolically place the government's official seal of approval on one religious view." "344

In addition, the court found that New York's kosher fraud statutes excessively entangled government and religion:

It appears to us that the challenged laws excessively entangle government and religion because they (1) take sides in a religious matter, effectively discriminating in favor of the Orthodox Hebrew view of dietary requirements; (2) require the State to take an official position on religious doctrine; and (3) create an impermissible fusion of governmental and religious functions by delegating civic authority to individuals apparently chosen according to religious criteria. 345

The court further cited to considerable disagreements within the Jewish community as to what standards must be met for food to be 'kosher' rejecting the contention that "no one disputes the meaning of the term 'kosher.'" 346

While New Jersey had simply replaced the kosher-fraud statute that had been invalidated in Ran-Dav with a simple kosher-disclosure regulation, the Commack decision in New York created more of an uproar. ${ }^{347}$ The governor proposed an "Emergency Kosher Law Protection Act" to replace the old kosher fraud statute, which combined a "disclosure [regulation] model with a requirement that kosher

340. See Commack, 294 F.3d at 420.

341. See, e.g., Sue Fishkoff, Red, White and Kosher, Editorial Opinion, N.Y. TimEs, July 3 , 2010, http://www.nytimes.com/2010/07/04/opinion/04fishkoff.html [hereinafter Red, White and Kosher].

342. See Commack, 294 F.3d at 425.

343. Id. at 431 (quoting Marsh v. Chambers, 463 U.S. 783, 792 (1983).

344. Id. (quoting Marsh v. Chambers, 463 U.S. 783, 792 (1983)).

345. Commack, 294 F.3d at 425 . Every other state with a kosher fraud statute has adopted language to this effect, specifically invoking the Jewish or "Hebrew" religion. Sigman, supra note 264 , at 551 n.237.

346. Commack, 294 F.3d at 425-26.

347. Sigman, supra note 264 , at 556 
be defined by 'the reasonable expectations' of consumers of kosher products, as well as generally accepted standards in the trade." ${ }^{348}$

The court in Commack may have drawn the correct conclusion under the first prong, but its analysis under the others proved troublesome. Its conclusion that the statutes in question define kosher as being in "accordance with the Hebrew Orthodox view" is inaccurate. ${ }^{349}$ Nowhere in the statute is any such definition provided; only advertising food as being "in accordance with the Hebrew Orthodox view" is prohibited if it does not actually comply with those standards. ${ }^{350}$ The legislature had neither taken a position as to religion nor preferred Orthodox dietary restrictions over other branches of Judaism. ${ }^{351}$ Rather than advancing or inhibiting religion, it was simply spelling out the simple legal characteristics of fraud. 352

The most controversial language in the original New York statute was its definition of kosher by reference to "the orthodox Hebrew religious requirements." 353 Courts and commentators who have considered the constitutionality of these laws have almost unanimously found that, statutes that defining kosher by reference to "the orthodox Hebrew religious requirements" violate the Establishment Clause. ${ }^{354}$

Those defending the constitutionality of kosher fraud statutes refer to the usage of kosher standards by those who are not religious as

348. Id. Then-Governor Pataki stated:

I am deeply disappointed that the U.S. Supreme Court has failed to review the decision of the U.S. Court of Appeals for the Second Circuit declaring certain provisions of New York's kosher laws unconstitutional. Our State's kosher laws are vitally important to tens of thousands of New Yorkers of all faiths and have protected generations of consumers from fraudulently packaged and misbranded products. I remain strongly committed to protecting New Yorkers who consume kosher products, and will promptly seek remedial legislation to ensure that those who purchase products labeled as kosher receive the full protection of our laws.

Id. at 556 n.276 (quoting Press Release, N.Y. Gov. George E. Pataki (Feb. 24, 2003)).

349. See Commack, 294 F.3d at $430,431$.

350. See N.Y. AGric. \& MkTs. Law §§ 201(a), 201(b)(1), 201(c), 201 (e)(2-a) \& (3-c), 201(f), 201(h) (Consol. 1991).

351. See id.

352. Cf. Popovsky, supra note 269, at 94-98. The New York Court of Appeals has defined fraud as "a representation of material fact, the falsity of that representation, knowledge by the party who made the representation that it was false when made, justifiable reliance by the plaintiff, and resulting injury." Centro Empresarial Cempresa S.A. v. América Móvil, S.A.B. de C.V., 952 N.E.2d 995, 1000 (N.Y. 2011) (internal quotations omitted).

353. See Popovsky, supra note 269 , at $92-93$.

354. See, e.g., Marci Ciesla, New York Kosher Food Labeling Laws Violate the Establishment Clause, LeARningACE.COM, http://www.learningace.com/doc/2783504/4f9031d2b42564760b7c9b 4d260683b8/rjlr_nd_61 (last visited Oct. 14, 2014). The current New York statute removes the offending language. See N.Y. AGric. \& MkTs. LAw \& 201-a to -d (Consol. 2013) (curing constitutional defect by removing references to "orthodox Hebrew requirements"). 
proof of the laws' secular purpose. ${ }^{355}$ That is, everyday consumers (whether Jewish or not) who buy kosher products for what they perceive to be reasons of health and purity - vegans, for example - might well find kosher products to be more attractive. ${ }^{356}$

Although the kosher food industry has burgeoned over the past three decades, enforcement of kosher-fraud statutes remains a local phenomenon-limited mostly to the large Jewish communities in the New York City metropolitan area, Baltimore, and southern Florida. ${ }^{357}$ After constitutional challenges struck down key provisions of those statutes, states "have been forced to reformulate their [kosher fraud laws]" along the lines of the current New Jersey disclosure model. ${ }^{358}$

Under this kind of statute, "a vendor who claims that a product is kosher [must be able] to show the basis for that claim." 359 "The state thus "need not involve itself in deciding the theological questions inherent in determining whether a particular food is kosher." 360 The consumer can thereby more easily "determine whether the product satisfies his particular religious [standards]." 361

As we shall see, the rabbis themselves often appear to find that a difficult issue to resolve. ${ }^{362}$

In the American penal system, prisoners are not entitled to the same constitutional rights as other citizens. ${ }^{363}$ Although, as the U.S. Supreme Court has noted, "prison walls do not form a barrier separating inmates from the protections of the Constitution," 364 the question of whether they are entitled to special considerations because of their religious beliefs has never been fully adjudicated.

In 1982, to determine whether "prison regulation impinges on inmates' constitutional rights," 365 the Court formulated its own rational

355. See, e.g., Popovsky, supra note 269 , at $87 \mathrm{n} .71$ and accompanying text.

356. See id. at 79 ; Sigman, supra note 264 , at 572 . Some courts are not moved by this argument. See, e.g., Ran-Dav's County Kosher, Inc. v. State, 608 A.2d 1353, 1356, 1364 (N.J. 1992) ("We remain unpersuaded by the repeated contention that the laws of kashrut have become secular norms.").

357. Sigman, supra note 264 , at 572 .

358. Id. at 572-73. "According to some industry insiders," enforcement of kosher fraud statutes has been of limited value, "because offenders simply view the penalties as the cost of doing business." Id. at 574 (internal quotation marks omitted). "[T] he problem . . might be that the fines and penalties are not sufficiently high [to have a deterrent effect]. $I d$.

359. Popovsky, supra note 269 , at 76 .

360. Id.

361. See Popovsky, supra note 269 , at 76.

362. See infra Part IV.B concerning the private policing of kosher dietary laws.

363. See Pi-wei Liu, Comment, A Prisoner's Right to Religious Diet Beyond the Free Exercise

Clause, 51 UCLA L. Rev. 1151, 1154 (2004).

364. Turner v. Safley, 482 U.S. 78, 84 (1987).

365. Id. at 89 . 
basis test: 1) is the government objective legitimate and rational; (2) is there an alternative to exercise the right despite the regulation; (3) what effect accommodating that right would have on prison officials and other prisoners; and (4) how difficult would it be to implement alternatives that would accommodate prisoner rights. ${ }^{366}$

The Court had a chance to apply its four-part test a few years later, in a case involving the right of Muslim prisoners in New Jersey to demand halal food. ${ }^{367}$ In Williams v. Morton, the Court held that providing vegetarian food, rather than halal, was rationally connected to the state's objective to provide a "simplified food service" while operating under budgetary constraints and while not additionally compromising prison security by allowing in meals from outside providers. ${ }^{368}$

Around the same time as Turner, the Tenth Circuit Court of Appeals rejected the lower court's finding that the prison was within its rights to reject Lafevers' request for a vegetarian meal plan. ${ }^{369}$ The circuit court rejected the lower court's reasoning that vegetarianism was only recommended rather than mandated by the Seventh-Day Adventist religion. ${ }^{370}$ The same conclusion would likely be reached in a court test of the kosher-fraud statutes. ${ }^{371}$

\section{The Raw Milk Controversy}

For some consumers, dairy products often carry as many dietary restrictions as meat. ${ }^{372}$ Prior to the Twentieth Century, when there was virtually no governmental regulation of milk, cheese, and butter, farmers would take raw milk from the cow and (usually after separating the cream in order to make butter) sell it to consumers. ${ }^{373}$

Although pasteurization of milk has since become the norm and the law, there is still much debate over the concept of raw milk. Its regulation is at a state-by-state level. In Iowa, for example, the sale of raw

366. Id. at 89-91.

367. Williams v. Morton, 343 F.3d 212 (3d Cir. 2003).

368. Id. at 218 . The court rejected out of hand the prisoners' contention that all administrative burdens could be alleviated if the entire meal program would switch to halal. Id. at 219. To do that would create the impression that the state favored the Muslim religion and would thereby violate the Establishment Clause. Id.; see generally Liu, supra note 367, at 1186 .

369. See LaFevers v. Saffle, 936 F.2d 1117, 1120 (10th Cir. 1991).

370. Id.; see also Liu, supra note 367 , at 1185.

371. Id. See also Liu, supra note 367 , at 1185 (providing that the "determination of what is required or not required would entangle courts ... in a debate of religious orthodoxy and doctrinal hermeneutics, not unlike the situation of New York State under the kosher fraud law").

372. See supra Part II.C.

373. See Phillips, supra note 171 , at 371 ; CARLISIE, supra note 165 , at 302. 
milk is illegal. ${ }^{374}$ It is allowed in other states to some extent, but there are strict rules that govern such sales. ${ }^{375}$

Modern health-conscious consumers are familiar with buzz-words created by the food-marketing industry: "all natural," "organic," "low sodium," " $0 \%$ trans-fat," "no cholesterol," "low sodium," "fat-free," "sugar-free," "gluten-free," and "chemical-free." 376 Some who consider themselves more sophisticated may regard such slogans as illusory..$^{377}$

Many people of the latter group have taken up the udders for raw milk-contending that pasteurization saps milk of many of its nutrients and unique health benefits. ${ }^{378}$ Some consumers claim that fresh, whole, unadulterated raw milk from grass-fed cows is effective as an antidote to cancer. ${ }^{379}$ However, the health benefits of raw milk and other raw products are strongly disputed by the Food and Drug Administration, which contends not only that raw milk is a less healthy choice, but also that it in fact is highly dangerous. ${ }^{380}$

Raw milk distributors and co-ops do not dispute the increased likelihood of pathogens. In fact, many co-ops require participants and customers to sign forms stating that they want the E. coli bacteria for its health benefits. ${ }^{381}$ While consumers often assert their right to choose what they eat regardless of the risk to health, the government contends that it has a compelling interest to ensure the public's health and welfare. The government bolsters its argument by pointing out that the risk of contaminated milk is increasingly likely due to the sheer volume of milk consumed by the American public.

374. Iowa CODE $\$ 192.103$ (2013).

375. See, e.g., 410 ILL.COMP. STAT. 635/8 (2014). Even chefs have come to the defense of those who want their milk unadulterated. See Dana Barrow, Raw Deal: California cracks down on an underground gourmet club, THE NEw YoRkeR, Apr. 30, 2012, at 32-33. "When you take milk or cream and pasteurize it and homogenize it," said one, "you've killed the originality." Id. (internal quotation marks omitted).

376. See e.g., Center for Science in the Public Interest, Promoting Safe, Nutritious FOOD FOR EVERYONE (2011), available at www.cspinet.org/about/pdf/CSPI_40th_AR.pdf.

377. See generally Center for Science in the Public Interest, Promoting Safe, NutriTIOUS FOOD FOR EVERYONE (2011), available at www.cspinet.org/about/pdf/CSPI_40th_AR.pdf.

378. See, e.g., "Raw Milk Seen As An Important Part of Natural-Cancer-Therapy Protocol, The Bovine, June 2, 2009, available at http:/thebovine.wordpress.com/2009/06/02/raw-milkseen-as-important-component-in-natural-cancer-therapy-protocol/.

379. Id.

380. See Questions and Answers: Raw Milk, FDA, (Nov. 1, 2011), http:/www.fda.gov/Food/ FoodborneIllnessContaminants/BuyStoreServeSafeFood/ucm122062.htm. According to the Center for Disease Control there have been " 2,659 cases of illnesses, 269 hospitalizations, [and] 3 deaths" due to the consumption of raw products. $I d$. Unpasteurized milk can contain pathogens such as E. coli and Listeria monocytogenes among others. Id.

381. See, e.g., Pure Food Co-op LLC Membership Form, a compelling interest to protect public health. 


\section{Holy Wars: Law, Politics, and Filthy Lucre}

Laws are like sausages. It is better not to see them being made. ${ }^{382}$

Over the past half-century, the constitutionality of various kosher fraud statutes has captured the attention of governments, courts, scholars, and the growing community of kosher consumers. As kosher food production burgeoned, ${ }^{383}$ its satellite industries-certifiers, supervisors, marketers, and others-created legal and practical problems of their own.

"[S]pecialized consumer protection statutes are [based upon] criminal law theories of public interest or social welfare." 384 They are thus currently treated as "traditional state functions", ${ }^{385}$ such as punishing fraud and protecting the right to practice one's religion freely and openly. On the other hand, such regulatory powers are often shared with "small, cohesive interest groups," like kosher consumers, who can act "within the political process to obtain special protection through statutes and regulations." 386

But there is relatively little evidence that the enactment of kosherfraud statutes plays a significant role in preventing willful kosher fraud. Nor do enforcement efforts address all of the problems facing kosher consumers today.

\section{A. "Something Ain't Kosher Here"}

As noted earlier, controversies about what is and what is not kosher can be dated back to early America, with the first recorded complaint about the sale of non-kosher meat coming in 1771 against the "Shochet Moshe."387

Purchasers of kosher food are generally sophisticated buyers, especially vigilant to identify questionable ingredients or fraudulent packaging. ${ }^{388}$ In fact, a good deal of kosher-fraud enforcement originates

382. Quotations Book, http://quotationsbook.com/quote/22577/ (last visited Mar. 20, 2013) (quoting Otto von Bismarck). "[T]he making of laws is like the making of sausages - the less you know about the process the more you respect the result" is another of several iterations of this famous quotation, which has most often been attributed to the aristocratic nineteenthcentury German Chancellor Otto von Bismarck (1815-1898), but its provenance and exactitude have been widely debated. See, e.g., BRAINYQuOTE, http:/www.brainyquote.com/quotes/ quotes/o/ottovonbis161318.html (last visited Mar. 20, 2013).; and Quote Investigator, http:// quoteinvestigator.com/2010/07/08/laws-sausages/.

383. See supra Part II.C.

384. Sigman, supra note 264 , at 601 .

385. $I d$.

386. Id.

387. See EIDLITz, supra note 60 , at 31.

388. See Sigman, supra note 264, at 538. 
with a consumer's observation or question. ${ }^{389}$ With them the slang expression "something ain't kosher here" resonates seriously. Consumers can also take action themselves, posting information in synagogues about questionable food manufacturers or naming suspicious retailers over the Internet." 390

Nor have kosher scandals have been unique to America. "In 1928, a crowd of 1,000 people threatened to storm Dubowsky's Restaurant in London, charging that the meat being served was non-kosher." Mounted police were called in to disperse the mob. In 1934, after the Third Reich had been installed in Germany, "rabbis warned that German Jews were being given non-kosher meat that had been made to look kosher and advised that the community might need to forego meat [while that was happening]." In 1964, a "French court sentenced two people for selling non-kosher meat as kosher." While the fines were small (one hundred francs), this was the first time that French Jews had been able to prosecute a kosher fraud case. Until then, the community had to rely on blacklisting the miscreants.

But the most blatant frauds are generally caught by kosher food inspectors and rectified by courts or government agencies. For example, in 1986 a record civil penalty - over $\$ 1$ million in fines - was levied by the New York State Department of Agriculture and Markets against Rachleff Kosher Provisions of Brooklyn, for "fraudulently label[ing] more than 33,000 pounds of non-kosher tongue, 14,000 pounds of brisket and 1,000 pounds of beef livers." 391

In 2006, in Monsey, New York, a wholesaler doing business as Shevach Meats was "caught stocking shelves at the Hatzlocha Grocery with non-kosher chickens that had been repackaged and labeled as kosher." The fraud had been going on for at least ten years before it was detected. Even then the discovery was by accident. "[O]ne of the owners of the grocery was told [offhandedly] by one worker of Kiryat Joel slaughterhouse", Shevach's supplier, "that the butcher had not received [chickens] from them in three weeks." Hatzlocha quickly "realized that it had been selling Kiryas Joel chicken the entire time, so they [called their kosher supervisors]." "The Mashgichim broke into the butcher's cooler at night and found [nineteen] cases of unmarked chicken." They tasted the skin, which was not salty, and they "found that the [birds'] kidneys were still intact" when they should have been "removed before salting." The supervisors summoned Shevach, which insisted that the poultry was Empire brand kosher

389. See id. a 565-66.

390. Sigman, supra note 264 , at 534,566 .

391. Id.; see also State of New York v. Rachleff Kosher Provisions, 591 N.Y.S.2d 64 (1992). 
chicken, an assertion that was quickly debunked by Empire. As a result, Shevach was ejected from Hatzlacha. Further investigation showed that for at least six months prior to being caught, "Shevach [sold] twice as much meat retail as he had bought from known [kosher slaughterhouses], not counting what it had sold wholesale[.]" Individual consumers came forward with stories that they had "noticed for months that the chicken [they bought] was less salty than usual." When they asked the butcher about it, they were told that its kashering process was now using a new low-sodium salt. Kosher consumers in Monsey were instructed to throw out or kasher all of their dishes, pots, and utensils.

All of the kosher meat sold in Los Angeles was distributed by two slaughterhouses, until a little before Passover 2013.392 The larger of them was Doheney Kosher Meats, under the supervision of the Rabbinical Council of California ("RCC"). ${ }^{393}$ The other was Western Kosher, certified by Kehilla Kosher. ${ }^{394}$ Then, in the early spring, "a video taken by a private investigator surfaced, purporting to show Doheny workers bringing in boxes of meat late at night without the required supervision of [a mashgiach]." 395 On March 7, 2013, the video was taken and subsequently aired on KTLA-TV Channel 5.396 The RCC immediately withdrew its supervision. ${ }^{397}$ Doheny's owner "later admitted to bringing unauthorized products to the store on two to three occasions." 398

392. Yerachmiel Lopin, How To Succeed in Kosher Without Really Trying, Frum FolliEs (Mar. 26, 2014), https://frumfollies.wordpress.com/2014/03/26/how-to-succeed-in-kosher-withoutreally-trying- $2 /$.

393. Id.

394. Id.

395. Id. (quoting Kate Mather, et al., Faith in a kosher butcher is shaken in wake of video, L.A. Times, Mar. 29, 2013, http://articles.latimes.com/2013/mar/29/local/la-me-kosher-butcher20130330 .

396. Kennedy Ryan \& Carolym Costello, Exclusive: Kosher Meat Scandal Rocks L.A. Market, KTLA (Mar. 28, 2013), http://ktla.com/2013/03/28/exclusive-kosher-meat-scandal-rocks-los-ange les-market/\#axzz2UJyVyiSF

397. Jonah Lowenfeld, Doheny Meats owner said to be involved in previous kosher controversy, Jewish Journal, Apr. 1, 2013, http://www.jewishjournal.com/los_angeles/article/doheny_ meats_owner_said_to_be_involved_in_previous_kosher_controversy.

398. Mather, supra note 418. Before issuing its decree, the RCC consulted with Rabbi Yisroel Belsky of the OU Kashrut Division who ruled that any "products purchased from [Doheny] prior to suspension of its certification" could still be considered kosher. Lopin, supra note 415. "But Kehilla Kosher, the RCC's main competitor," rejected Belsky's relatively lenient ruling questioning whether "there [was] a halachic need to kosher utensils in private homes or at catering establishments." Id. (emphasis in original). 


\section{B. Kosher Certification Agencies}

The larger kosher certifying agencies "aggressively pursue unauthorized use of their trademarks," recalling mislabeled products and publicizing them in "commonly-read Jewish publications." 399 Such matters rarely make it to the courts, however, observant Jews usually following a religious dictate that discourages or prohibits them from suing one another in secular surroundings - more often choosing to bring the matter before a rabbinical arbitration panel (bet din). ${ }^{400}$

Prior to the mid-twentieth-century, when preparation of family meals was almost exclusively the province of a housewife cooking in her own kitchen, the dietary rules were second nature to Jewish women. They knew intuitively that virtually all fruits and vegetables, dairy products, and common condiments were clearly kosher, and that others (pork, shellfish, insects) were not. They bought their meat from a kosher butcher shop and fish from an open market, and relied on their rabbis to tell them which bakeries were acceptable. ${ }^{401}$

Since the mid-Twentieth Century, however, modern marketing has revolutionized supplying the kosher kitchen. Processed foods are ubiquitous. The observant housewife can now serve variations of anything from bacon to cheeseburgers to crab salad. She has also been taught how to check the kashrut of vegetables (lettuce, broccoli, and strawberries), dairy items (ice cream, sour cream, and whipped cream), and popular drinks (water, wine, and whiskey). The previously informal guidelines have been largely replaced by required symbols of kosher certification agencies. ${ }^{402}$

Currently there are at least one hundred such services, each with a distinctive symbol clearly marked on the packaging labels of the foods being supervised. ${ }^{403}$ The stamps of approval come in all shapes (Circle K, Diamond K, Heart K, Triangle K) and from far and wide (California K, Florida K, Earth K). ${ }^{404}$ Certification companies oversee everything from hidden ingredients, like chemicals and colorings to

399. Sigman, supra note 264, at 567; but see Levy v. Kosher Overseers Ass'n of Am., Inc., 104 F.3d 38 (2d Cir. 1997) (O-K Laboratories brought suit to enjoin the Kosher Overseers Association (KOA) from using its encircled $\mathrm{K}$ symbol).

400. Sigman, supra note 264, at 568 (citing Ira Yitzchak Kasdan, A Proposal for P'sharah: $A$ Jewish Mediation/Arbitration Service, JLAw.COM, http:/www.jlaw.com/Articles/psharah1.html (last visited Mar. 20, 2013), (discussing the prohibition and presenting alternatives to the rabbinical courts)).

401. See Sue Fishkoff, Kosher Nation: Why More and More of America's food An SWErs to a Higher Authority 47 (1st ed. 2010).

402. See KosherQuest, supra note 27.

403. See, e.g., Reliable Certifications, KosHERQuEst, http://www.kosherquest.org/symbols.php (last visited Oct. 14, 2014) [hereinafter Reliable Certifications].

404. See, e.g., Eidlitz, supra note 60, at 11-29. 
products that, according to most, rabbinic authorities do not, such as aluminum foil, bottled water, and fresh fruit sold in supermarkets. ${ }^{405}$ They cover specialty confection stores from Cinnabon to Dunkin' Donuts, to selected kosher franchise stores of international restaurant chains like McDonald's and Subway. ${ }^{406}$

Kosher food is now available in venues far outside the supermarket, from sports arenas to amusement parks. Although there was no special kitchen, strictly kosher food was available for both athletes and the general public at the Olympic Games in London in the summer of 2012. Provisions were also made for athletes and "spectators who follow Halal diets." In the Olympic Village, there were "rows of serving counters under colorful signs proclaiming a commonwealth of catering such as Indian, African and Caribbean, halal, Mediterranean, kosher."

Even prescription medicines now fall under kosher supervision. In May of 2014, Pfizer, the world's largest research-based pharmaceutical company, announced that the Orthodox Union had granted kosher certification "to ELELYSO" ${ }^{\mathrm{TM}}$ (taliglucerase alfa) . . . , an enzyme replacement therapy for the long-term treatment of adults with a confirmed diagnosis of Type 1 Gaucher disease." It was the "first prescription medication to be certified kosher by the OU[.]"

It was estimated that the kosher industry in the United States is a $\$ 30$ billion a year business with as many as "one third of all products" on supermarket shelves under some sort of certification. 407 Only a "small part of this market (about $\$ 2$ billion)," is made up of Orthodox Jewish consumers, which simply reflects the rapidly growing interest in kosher food among other groups. ${ }^{408}$ Some of them, such as Seventh-Day Adventists and Muslims, adhere to dietary laws out of religious conviction; others, such as vegetarians, do so for health reasons. ${ }^{409}$ Still more - perhaps the majority - feel kosher certifica-

405. See id. at 154

406. See generally Archive: USA, YesThatsKosher.com, http://yeahthatskosher.com/cate gory/united-states/ (last vised Dec. 29, 2013) (references to kosher Cinnabon, Dunkin' Donuts, and Subway). See Products that Don't Need Certification, KosherQuest, http://www.kosher quest.org/kq_noneneeded.php?s'0\&q'noreq (last accessed December 29, 2013).

407. Reliable Certifications, supra note 426 (under Introduction to Kosher Certification); see also As Kosher Food Becomes Big Business Transformation Not Always Smooth, JTA, July 26, 1993, http://www.jta.org/1993/07/26/archive/as-kosher-food-becomes-big-business-transforma tion-not-always-smooth [hereinafter As Kosher Food Becomes].

408. Reliable Certifications, supra note 426.

409. See Reliable Certifications, supra note 426. Current industry statistics profile the average kosher consumer as under 40 years old, and in the market for "gourmet, upscale and healthy foods." 25th Annual Kosherfest 2013 Encompasses Foods from Throughout the World, PRWEB .COM (Nov. 5, 2013), http://www.prweb.com/releases/2013/11/prweb11301056.htm. "According to various sources, the number of kosher consumers in the U.S. [exceeds] 12 million." Id. There are over ten thousand kosher producing companies, and "200,000 kosher certified products." Id. 
tion is their best guarantee that ingredients have been carefully processed and the final products are relatively pure. According to a recent study, "at least five million people buy products based on their being kosher." 410 It's little wonder then that many large corporations have found it profitable to acquire companies that are under kosher supervision.

By far the largest certification agency is the OU, which supervises "nearly 500,000 products" and visits processing plants on every continent in the world. It employs close to one thousand supervisors and fifty rabbinic coordinators. ${ }^{411}$ Although the OU has always been a non-profit organization, over the past half-century more than a hundred new agencies around the world, each of course bearing its own distinctive symbol, have entered the field for the usual corporate goal - to make money - proving as well that kosher supervision benefits the food processor as much as it does the consumer. ${ }^{412}$ The OU, which (unlike the other certifying agencies) does not solicit business, claims that fewer than a dozen companies have discontinued supervision because sales did not subsequently increase. ${ }^{413}$

To become certified by the OU, the processor must supply a comprehensive "list of every ingredient in the product, including preservatives, stabilizers," and other additives, as well as all other products made on the premises. ${ }^{414}$ Likewise, each "step in the manufacturing process, [including] cleansing agents used on the equipment," must be reviewed and evaluated. ${ }^{415}$ Each ingredient is tracked to its source. ${ }^{416}$

No meat product is kosher if the animal or slaughtering process has not met strict rabbinic standards. ${ }^{417}$ The same is true with wines and cheeses. ${ }^{418}$ Ingredients that are apparently innocuous, such as "natural colors," "softeners," and "artificial flavors," may in fact be derived from insects, non-kosher animals, or fish. ${ }^{419}$ Even if they are inherently kosher, some foods can be declared treif if they are found to contain insects or rodent parts. The kosher supervisors are well aware

"Forty percent of kosher sales occur" around the Passover holiday. Id. "[T]he dollar value of kosher products produced in the USA is $\$ 305$ billion." Id.

410. Reliable Certifications, supra note 426.

411. FishкoFf, supra note 424 , at 46.

412. See Eidlitz, supra note 60 , at 32.

413. Peter Sinton, More Businesses Are Converting to Kosher, SF GATE, Apr. 1, 2001, http:// www.sfgate.com/business/article/More-Businesses-Are-Converting-to-Kosher-2936135.php.

414. EIDLITZ, supra note 60 , at 2 .

415. Id.

416. Id.

417. Id.

418. Id.

419. Eidlitz, supra note 60 , at 2 . 
of the "tolerance levels" that are promulgated by the Food and Drug Administration, which are not always as strict as the religious dietary rules. ${ }^{420}$

Once all of the ingredients and manufacturing processes are approved by rabbinic supervisors, the agency "determine[s] how much on-plant supervision is needed." 421 Disclosure of this information is made part of the contract, which also requires that the manufacturer cannot change either "ingredients or suppliers without prior written consent of the agency." 422 An on-site inspector (the mashgiach) is supposed to ensure that the company is in compliance. ${ }^{423}$

As previously mentioned, penalties for violations can be uncompromising. An agency that finds its symbol unauthorized or misused can sue under trademark law, seek an injunction to prevent future unauthorized usage, or seek damages to compensate for any harm from the infringement. ${ }^{424}$ Some courts have allowed restitution based upon the profits of the infringing party. ${ }^{425}$

When certifiers discover "instances of mistake or fraud (whether accidental, negligent, reckless, or willful)," they can order immediate corrective action or drop their certification. ${ }^{426}$ The public is generally notified via community newspapers, trade publications, and product recalls.427 As might be expected, willful fraud brings harsher penalties.

Because it is often difficult to ascertain whether a product mislabeled as kosher resulted from an honest mistake or from intentional misrepresentation, certifiers rarely invoke the term "fraud." 428 Moreover, given the ambiguity of the term kosher and the potential for legal liability, a supervising agency will usually not declare a product or food establishment as non-kosher. ${ }^{429}$ Instead, it will announce that

420. See David Bistricer, Here's the Buzz on Certifying Veggies as Insect Free, Ou KosHER, (May 1, 2006), http://oukosher.org/blog/industrial-kosher/heres-the-buzz-on-certifying-veggiesas-insect-free/.

421. EIDLITZ, supra note 60 , at 3.

422. $I d$.

423. Id. The individual supervisor is generally paid by the supervising agency for each visit he makes to the processing plant. Id.

424. See supra Part III.B.

425. Id. See Sigman, supra note 264, at 550. Certification marks are protected under 15 U.S.C. $\S \S 1117$ (a)-(b), 1127 (2006) (providing for the right of recovery for violation of a registered mark). "If the damages are either inadequate or excessive, the court may affix 'such sum as the court shall find to be just." Sigman, supra note 264 , at 550 n.232 (citing 15 U.S.C. $\S 1117$ (a)). "This statute provides statutory damages for counterfeit marks as well." Id.

426. Sigman, supra note 264 , at 562 .

427. Id. at 562 .

428. Id. at 563-64.

429. Id. 
it no longer certifies the product or restaurant. ${ }^{430}$ In neither instance (prospective or retroactive decertification) is the agency likely to confirm or deny that the food is actually kosher, instead choosing euphemistic code phrases like "not recommended." 431

There are times when the fault rests with the supervisor. In the summer of 1990, a mashgiach working for the Rabbinical Council of Greater Washington at the Moshe Dragon Chinese restaurant in Silver Spring, Maryland, discovered what he thought were non-kosher ducks. ${ }^{432}$ Although the "Rabbinical Council eventually cleared the restaurant owner of any wrongdoing and fired its own supervisor," word of the dispute spread nevertheless. ${ }^{433}$ The owner claimed that, because of the rumors and innuendo, he had lost over $\$ 30,000$ and was forced to sell the business. ${ }^{434}$

\section{Law and Politics in the Business of Kashrut}

It is a fact of modern life that kosher supervision nowadays has considerably less to do with halachic principles than with personalities and business considerations - egos, the politics of control, and profit motives - in short, lots of dollars changing hands. Rabbis and administrators of certification agencies, each with differing standards of what is kosher, often appear engaged in a war for minds and money with the kosher consumer caught in the middle.

Virtually everywhere there are kosher consumers there are kosher controversies. This is of course the case in the Jewish State where, for example, a dozen Jerusalem restaurants recently claimed to have kosher credentials although they were without the official government imprimatur. ${ }^{435}$ The restaurants challenged the Orthodox Rabbinate's monopoly over kosher supervision, especially where supervisors seldom inspect their premises. ${ }^{436}$ The restaurants argued that "they enforce kashrut in their kitchens on their own without any rabbis or

430. Id. at 564.

431. Sigman, supra note 264 , at 564 . Retroactive decertification occurs mostly in the packaged-food industry. $I d$.

432. $I d$. at 563. The supervisor also found "receipts from a non-kosher supplier. Id. See also Ruth Sinai, Is Everything Kosher with Moshe Dragon's Duck?, Associated Press, July 4, 1990, http://www.apnewsarchive.com/1990/Is-Everything-Kosher-With-Moshe-Dragon-s-Duck-/id-581 bffefacbb102da9f0e $960882 \mathrm{fb} 652$.

433. Sigman, supra note 264 , at 563 .

434. $I d$. at 563 .

435. Nathan Jeffay, Kosher Restaurant Revolt Brews in Jerusalem, JewiSH DaILy ForwaRD, Nov. 11, 2012, http:/forward.com/articles/165707/kosher-restaurant-revolt-brews-in-jerusalem/ $? \mathrm{p}=$ all.

436. Id. 
inspectors." ${ }^{437}$ Though the kitchens are checked regularly by rabbinical students, Israel will offer an alternative certificate that will open kitchens "for all customers to inspect and checked regularly on a volunteer basis by rabbinical students." 438

\section{Dogma $^{439}$}

Hot dogs are as American as apple pie on the Fourth of July. They are also consumed around the world, from Australia to Zambia, and have become a major part of the increasingly capitalistic fast-food business in communist China and Russia. We bite into more than 20 billion of them each year in this country alone ${ }^{440}$ - some 818 every second from Memorial Day to Labor Day, according to the National Hot Dog \& Sausage Council ("NHDSC").441

A question that seldom gets asked, except in Orthodox Jewish circles, is whether kosher hot dogs really kosher? Though the term may have become generic, its halachic authenticity under halachah (Jewish rules and regulations) is important to observers of the dietary laws, and of even more significance to those who eat only meat that is considered kosher according to the most stringent standards. ${ }^{442}$

Hot dogs make up a $\$ 4$ billion-a-year business, ${ }^{443}$ a large share of which is the kosher market - "six million Americans", according to the NHDSC, only "a quarter of whom are Jewish". ${ }^{444}$ And that number is growing at twice the rate of consumption of all other hot dogs. ${ }^{445}$ Little wonder, then, that the controversy surrounding the He-

437. $I d$.

438. $I d$.

439. Parts of this section appear in an earlier article by the author. See Kenneth Lasson, "Hebrew National and Kosher Politics: What's Kosher About Answering to a Higher Authority?," Baltimore Jewish Times (July 10, 2009). That description of the kosher wars spread quickly over the Internet, and launched a fiery cyberspace dispute about the appropriate standards to be applied for kosher certification. See, e.g., Hebrew National and Kosher Politics: When being Kosher Isn't Kosher Enough?, FAIledMessiah.COM (July 13, 2009), http:// failedmessiah.typepad.com/failed_messiahcom/2009/07/hebrew-national-and-kosher-politics-234 .html; Are Hebrew National Hot Dogs Really Truly No-Kidding Kosher?, The Talmudic Blog (June 9, 2014), http://tzvee.blogspot.com/2009/07/jewish-times-are-hebrew-national-hot.html.

440. See Hol Dog Fast Facts, National Hot Dog and Sausage Councll, http://www.hotdog.org/culture/hot-dog-fast-facts (last visited Mar. 20, 2013).

441. See Consumption States, National Hot Dog and Sausage Council, http://www.hotdog.org/ht/d/sp/i/38567/pid/38567 (last visited Mar. 20, 2013).

442. For a more detailed discussion of glatt kosher, see infra Part V.B.

443. Associated Press, New Attack Ad Targets Hot Dogs, Citing Dubious Cancer Risk, Fox News, (Aug. 26, 2008), http://www.foxnews.com/story/2008/08/26/new-attack-ad-targets-hotdogs-citing-dubious-cancer-risk/.

444. Kosher Hot Dogs, National Hot Dog and Sausage Council, http:/www.hot-dog .org/culture/kosher-hot-dogs (last visited Mar. 20, 2013) [hereinafter Kosher Hot Dogs].

445. Id. 
brew National brand - which was recently rated by Consumer Reports as the best in overall quality of all the hot dogs it rated ${ }^{446}$ is mushrooming by the day.

The Hebrew National Kosher Sausage Factory, founded in 1905 on the Lower East Side of Manhattan, processed kosher meats for New York's numerous delicatessens serving neighborhoods of predominantly Eastern European Jewish immigrants. By the middle of the Twentieth century, Hebrew National had become the largest, most recognized kosher brand in the United States. ${ }^{447}$ In 1960s, the company launched its famous "We Answer to a Higher Authority" advertising campaign, ${ }^{448}$ a slogan that sold the concept of kosher as if it were an imprimatur of quality assigned to premium brands. In the process, of course, Hebrew National's reputation for using pure beef without artificial colorings or flavoring additives was duly enhanced. ${ }^{449}$ The dramatic increase in sales that followed was not lost on the larger business community. In 1993, the food conglomerate ConAgra bought the company. ${ }^{450}$ In 2004, it built a state-of-the-art kosher processing plant in Quincy, Michigan ${ }^{451}$ and handed its kosher supervision to a well-known rabbi from Brooklyn, "pronounc[ing] the [hot dogs] kosher enough for Conservative Jews." 452

More than one prominent Orthodox rabbi has suggested that modern kashrut "is two percent halachah and 98 percent ego and money and politics," which might explain why many of the people whom the author interviewed spoke on condition of anonymity. ${ }^{453}$ One of them was a small kosher caterer who said, "You'll never get the full skinny on kashrut supervision" - intimating the prevailing business ethic that political and monetary considerations are paramount to candor. ${ }^{454}$

Insuring the kashrut of meat is a complicated process, from the relatively simple strictures provided in the Torah to the detailed practices that have been interpreted and promulgated by rabbinic scholars over

446. See Consumer Reports Ranks Hot Dogs and Light Beer, Popsugar (June 8, 2007), http:// www.fitsugar.com/Consumer-Reports-Ranks-Hot-Dogs-Light-Beer-298948. Oscar Mayer, the world's largest producer of hot dogs, came in eighth.

447. Once Upon a Hot Dog, Hebrew National, http://www.hebrewnational.com/hebrew-na tional-history (last visited Nov. 26, 2014).

448. Id.

449. Id.

450. Company history timeline, ConAgra Foods, http://www.conagrafoods.com/our-company/company-history (last visited Nov. 26, 2014).

451. Alex Sanz, Hebrew National Plant to Close, WTHR.com, (Jan. 2, 2004), http://www.wthr .com/story/1585458/hebrew-national-plant-to-close.

452. See Red, White and Kosher, supra note 344.

453. See Lasson, supra note 467 (Interview in Baltimore, Md. (Oct. 2013)).

454. Id. (Interview in Baltimore, Md. (July 2009)). 
the centuries. Disputes among Orthodox authorities regarding precise interpretations of halachic parameters have existed for ages, but most will agree that there is a well-defined objective standard. Meat above this baseline is kosher; below it, treif. ${ }^{455}$

Which kosher agency is considered the most reliable? While it may be hard to get a definitive answer from anyone who has a stake in the business - it is clear that what it boils down to is a matter of trust. Strictly Orthodox kosher consumers are generally faithful to their chosen rabbis - many of whom in turn, however, appear to be more subject to peer pressure than they are knowledgeable about the technicalities of kashrut.

Some organizations, such as the Star-K, like to consider their kash$r u t$ standards as the strictest. But that level of rectitude can be difficult to identify, especially when it is determined by one person - in this case Rabbi Moshe Heinemann, the group's rabbinic administrator. ${ }^{456}$ "[He] basically determines what the standard is," said [Avrom] Pollak, Star-K's president. ${ }^{457}$ The agency also takes into consideration the context in which the product is marketed. "If [it] has a lewd message or is the kind of product that kosher consumers may find offensive, we may elect not to certify it." 458

For example, when the Star-K was asked to certify the kashrut of a cruise ship, it felt it had to ensure that religious couples would be able to secure separate beds in order to adhere to "the laws of family purity." 459 "If they were bolted to the ground and together," said Pollak, "that could be a problem." 460 Similarly, the agency might decline supervising a hotel whose ballroom overlooked a swimming pool with women in bikinis, or restaurants that featured female singers. ${ }^{461}$

It is a subject of some fascination that many Orthodox Jews will not eat any Hebrew National meat products. The underlying reasons for this irony are a hodgepodge of halachah and rabbinic infighting power, profits, and politics - much of which is as juicy and spicy as what goes into the common sausage. ${ }^{462}$

455. See Kashrut: Jewish Dietary Laws, JuDAISm 101, http:/www.jewfaq.org/kashrut.htm (last visited Mar. 20, 2013).

456. Maayan Jaffe, The Kosher Machine, Baltimore Jewish Times, Aug. 7, 2013, http://jew ishtimes.com $/ 9254 /$ the-kosher-machine/2/.

457. Id. (internal quotation marks omitted).

458. Id.

459. Id.

460. Id. (internal quotation marks omitted).

461. Jaffe, supra note 485.

462. From whence the wiener? One of the oldest forms of processed food, the common sausage can be traced as far back as the Greek Empire, having been mentioned within Homer's The Odyssey. See Hot Dogs - History and Legends of Hot Dogs, WhatsCookingAmerica.com, 
In 2004, Hebrew National decided to change from its longtime inhouse kosher quality control to an independent supervisory authority - the Triangle $\mathrm{K}$ - to put into place the strict standards required by halachah. ${ }^{463}$

Of the major brands under Triangle $\mathrm{K}$ supervision (which include Sunmaid, Minute Maid, Wonder Bread, Del Monte, Frito-Lay, Mogen-David, Birds Eye, Ocean Spray, Hawaiian Punch, and Mott's), Hebrew National presents the most complicated logistics. ${ }^{464}$ It is a huge operation. It took the Triangle K's rabbinic leader, Aryeh Ralbag two years to set up Triangle K's certification process for Hebrew National. ${ }^{465}$ To keep the supply of meat flowing requires four slaughtering houses, one salting facility, and a central processing plant - all under round-the-clock rabbinical supervision. ${ }^{466}$

A decade ago, soon after Triangle $\mathrm{K}$ took over, the top lawmaking body of the Conservative movement issued its seal of approval for all Hebrew National meat products. ${ }^{467}$ The decision was supposed to have a large impact on religiously observant Conservative Jews, especially those living in smaller communities with limited access to kosher food. ${ }^{468}$ The number of Conservative customers account for only a small share of the kosher market. ${ }^{469}$

Orthodox Jews, however, continued to stay away in droves, for reasons that appear to be largely bound up in rumor, innuendo, and am-

http://whatscookingamerica.net/History/HotDog/HDIndex.htm (last visited Mar. 20, 2013). The origin of the term "hot dog" is in some dispute. Visitors to the 1893 Columbian Exposition during the Chicago World's Fair consumed large quantities of the sausage sandwiches, which in the same year became the standard fare at baseball parks. Id. They were also current at Yale as early as 1894, when "dog wagons" sold them at the dorms - the name a sarcastic comment on where the meat came from. Id. For a more complete history of hot dogs, see JoHN A. JAkLE \& Keith A. Sculle, Fast food: Roadside Restaurants in the Automobile Age 163 (Johns Hopkins Press 1999).

463. Miriam Colton \& Steven Weiss, Hebrew National Certified Kosher - But Not Kosher Enough for Some, JEwish DaILy ForwaRd, June 11, 2004, http://forward.com/articles/5806/he brew-national-certified-kosher-e-but-not-koshe/.

464. Lasson, supra note 468.

465. Id.

466. Id. "Our mashgichim are carefully selected, scrutinized and regularly tested for their knowledge of constantly changing technology," according to Rabbi Ralbag. Id. (internal quotation marks omitted). "They are all God-fearing men who learn every night; all are well-paid and work three-day weeks, with substantial rest periods," he said. Id. The overwhelming majority of mashgichim worldwide are men, although there is currently a movement to allow women to serve in that role. See Emunah sues Chief Rabbinate to allow female kosher supervisors, JTA, July 7, 2013, http://www.jta.org/2013/07/07/news-opinion/israel-middle-east/emunah-sues-chiefrabbinate-to-allow-female-kosher-supervisors\#ixzz2YToGrpjW.

467. See Red, White and Kosher, supra note 344.

468. Lasson, supra note 468.

469. Id. 
biguity. Many ostensible adherents to strict halachah consider Triangle K to be "unreliable." 470 Others refrain from buying Hebrew National because its meat is not "glatt kosher." 471

\section{"Glatt" or Not?}

The term "glatt kosher" is used to describe a more expensive and complicated form of rabbinical supervision that requires the lungs of a ritually slaughtered animal to be smooth (glatt) and carefully scrutinized for imperfections. ${ }^{472}$ If no imperfections are found, the animal is certified as glatt. ${ }^{473}$ In fact this was normal standard throughout Europe for centuries. ${ }^{474}$ The Code of Jewish Law (Shulchan Aruch) describes many types of adhesions in intricate detail, many of which render the animal non-kosher. ${ }^{475}$ Although minor imperfections do not render it non-kosher, many Orthodox Jews choose not to buy meat that falls below the higher standard.

This has become a subject of considerable controversy - all the more so because a number of knowledgeable rabbis feel that the term glatt has been diluted to the point that it is nowadays more a marketing tool than a guarantee of superior purity. ${ }^{476}$ Relatively few animals, in fact, truly meet the original standard. ${ }^{477}$

But non-glatt meat, if inspected properly, is $100 \%$ kosher. 478 On the other hand, "misconceptions about the meaning of glatt are ... widespread." 479 Although it is technically inaccurate to label chicken, fish, lamb, or dairy products as glatt, such labeling is a common practice. ${ }^{480}$ In fact it has evolved into a marketing tool, and is now applied to all manner of food having nothing whatever to do with smooth lungs in kosher cattle. Consumers who read the fine print may now see "Glatt Kosher" label on everything from airline meals that contain no meat, to pizza ("Glatt Dairy"), to fruits and vegetables ("Glatt Pareve"). ${ }^{481}$

470. Red, White and Kosher, supra note 344.

471. $I d$.

472. See What Is Glatt?, InNovation Within Tradition, http://www.kosherveyosher.com/ old-world-kashrus-1263.html (last visited Mar. 20, 2013).

473. $I d$.

474. See The Satmar Glatt Meat That Really Isn't Glatt At All, FailedMessiah.com, (Jan. 14, 2014), http://failedmessiah.typepad.com/failed_messiahcom/2014/01/the-satmar-glatt-meat-thatisnt-really-glatt-at-all-345.html?cid=6a00d $83451 \mathrm{~b} 71 \mathrm{f} 69 \mathrm{e} 201 \mathrm{a} 510 \mathrm{efbb} 48970 \mathrm{c}$.

475. Id.

476. See, Is it Kosher?: Shechita, KosherQuest, http://www.kosherquest.org/book.php?id= SHECHITA_THROUGH_BUTCHER.htm (last visited Oct. 14, 2014).

477. Id.

478. Zivotofsky, supra note 23.

479. Id.

480. Id.

481. See id. 
When Hebrew National switched to Triangle K, the Jewish newspaper The Jewish Daily Forward editorialized that, although the stricter glatt standards "could help put an end to the string of urban legends and sordid explanations for why Orthodox Jews won't consume [Hebrew National's products], . . . for a variety of sociological and religious reasons, the decisions are unlikely to translate into a significant increase in sales." 482 That prediction has proven largely accurate.

But glatt continues to mean different things to different people. "What's glatt in Cleveland might not be glatt in Baltimore," according to Rabbi Don Maskovitz, one Orthodox mashgiach who works for several kosher certification organizations. ${ }^{483}$ "Many people follow the higher glatt standard," he said, "but there's nothing wrong with Rabbi Ralbag's hashgachah[;] Hebrew National has to overcome some problems with its historical reputation." 484 Moreover, there are many Orthodox Jews - especially in smaller Jewish communities around the country -who do not limit themselves to glatt meat but still consider themselves strictly kosher. ${ }^{485}$

Kosher food processors can also run afoul of their own employees. In May of 2012, ConAgra Foods was sued by a group of former workers, who alleged that the slaughtering floor at a major Hebrew National plant fell short of the standards necessary to be called kosher. ${ }^{486}$ According to the complaint, packages with a "Triangle K" symbol represent that the contents are kosher "as defined by the most stringent Jews who follow Orthodox Jewish law." 487 As a result, claimed the plaintiffs, ConAgra not only misled consumers bur charged premium prices. ${ }^{488}$ "This is an invisible fraud," said a lawyer for the plain-

482. Miriam Colton \& Steven I. Weiss, Hebrew National Certified Kosher - But Not Kosher Enough for Some, THE Jewish DaILY Forward, June 11, 2004, http:/forward.com/articles/ 5806/hebrew-national-certified-kosher-e-but-not-koshe/.

483. See Lasson, supra note 468 (internal quotation marks omitted).

484. Id. (internal quotation marks omitted).

485. See, e.g., Colton, supra note 510 (explaining that the head of the Orthodox Union's kashrut department, Rabbi Menachem Genack, told The Jewish Daily Forward that while the OU once certified both glatt and non-glatt meat, in the 1970s "market conditions" caused the organization to limit its supervision only to the former.).

486. See JTA, Hebrew National Faces New Kosher Hearing, Jewish Daily Forward, Aug. 1, 2012, http:/forward.com/articles/160331/hebrew-national-faces-new-kosher-hearing/.

487. Id. (internal quotation marks omitted).

488. Audrey Yoo, Hebrew National's Hot Dogs Aren't Actually Kosher, Claims Lawsuit, Time NewsFEed, (June 19, 2012), http://newsfeed.time.com/2012/06/19/hebrew-nationals-hot-dogsarent-actually-kosher-claims-lawsuit/. The class-action suit, Wallace v. ConAgra Foods, Inc., 920 F. Supp. 2d 995 (D. Minn. 2013), was filed by non-kosher consumers who challenged Hebrew National's claim that its products were " $100 \%$ kosher." The suit sought monetary damages equal to the total amount spent on Hebrew National products by those in the class. See Wallace, 920 F. Supp. 2d at 996. 
tiffs. ${ }^{489}$ "How does a consumer who thinks he is buying kosher meat really know he is buying kosher meat? It's a very, very difficult thing for a consumer to detect, unless someone investigates." 490

ConAgra moved to dismiss the suit. "The allegations in the complaint regarding AER are completely and utterly false," the company said.491 Moreover, the word kosher is "exclusively a matter of Jewish religious doctrine," it argued, and under the First Amendment "federal courts may not adjudicate disputes that turn on religious teachings, doctrine and practice." 492 In early 2013 , a federal court in Minnesota agreed, ruling that because "kosher is a religious standard" . . . subject for rabbinic debate - not a federal court ruling." 493

But in the world of kashrut, courts do not always have the last word in the word. While, a spokesperson for the OU said, "we do not comment on other kosher certifications," the response was different, from the Kashrut Hotline of the Baltimore-based Star-K organization. ${ }^{494}$ "You should not eat Hebrew National," when asked why, she said the Triangle K "is not considered reliable." 495

The typical onus placed by Star-K and others on products they deem non-kosher is "Not Recommended" - a term ostensibly used to avoid corporate lawsuits for restraint of trade or defamation of trademark. ${ }^{496}$ But consumers relying on such agencies will stay away from

489. Yoo, supra note 516 (internal quotation marks omitted).

490. Id. (internal quotation marks omitted).

491. Jonathan Stempel, Hebrew National Hot Dogs Not Kosher, Lawsuit Claims, ReuTERs, June 19, 2012, http://in.reuters.com/article/2012/06/18/conagra-lawsuit-hebrewnational-idINL1E8 HICXD20120618.

492. Memorandum in Support of Defendant ConAgra's Motion to Dismiss the First Amended Complaint at 1, Wallace v. ConAgra Foods, Inc., 920 F.Supp.2d 995 (2012) (No. 0:12cv-01354-DWF-TNL); see also JTA, supra note 514. Triangle-K, Hebrew National's kosher certifying agency, also rejected the anonymous allegations, claiming that they had been made by former slaughterhouse employees who had been fired for cause. See JTA, Hebrew National Rejects Claim It's Non-kosher, JewISH DaILy Forward, June 19, 2012, http://forward.com/arti cles/158088/hebrew-national-rejects-claim-its-non-kosher/.

493. JTA, Lawsuit against Hebrew National Dismissed, Jewish Press, Feb. 2, 2013, http://www .jewishpress.com/news/breaking-news/lawsuit-against-hebrew-national-dismissed/2013/02/02/; Wallace, 920 F. Supp. 2d at 999.

The definition of the word 'kosher' is intrinsically religious in nature, and this court may not entertain a lawsuit that will require it to evaluate the veracity of Defendant's representations that its Hebrew National products meet any such religious standard. Because all of Plaintiffs' claims derive from Defendant's alleged misrepresentation that its Hebrew National products are ' $100 \%$ kosher,' all counts of the Amended Complaint are barred by the First Amendment.

Wallace, 920 F. Supp. 2d at 99.

494. Lasson, supra note 468.

495. Id.

496. See, e.g., Star-K Liquor List, STAR-K (June 2011), available at http://www.star-k.org/ cons_appr_liquor_list.ind.pdf. 
"not recommended" purveyors or caterers like the plague. They also are influenced when supervisors take out advertisements in local newspapers declaring that a business is "no longer under our supervision" - without specifying the reasons why or noting that another agency has assumed the certification. ${ }^{497}$ The stigma sticks, and tends to stay.

Because of the extra costs associated with slaughtering and supervision, kosher meat is already considerably more expensive than nonkosher, and glatt adds to the cost. Thus, mixing the two allows the less scrupulous merchant to keep his prices down while making more of a profit. In March of 2013, the Doheny Glatt Kosher Meat Market was accused of selling glatt kosher" meat that was not in fact glatt. 498 A class-action lawsuit was filed against the market alleging fraud and false advertising. ${ }^{499}$ In April, the U.S. Department of Agriculture launched an investigation. 500 The Rabbinical Council of California suspended its certification..$^{501}$

Rabbi Aron Abadi, who publishes an influential website called Kashrut.org, speaks bluntly about the multimillion-dollar kosher supervision business:

You want to do business in this industry, you need to follow the rules of the 'Kashrut Mafia.' Ask anyone in the food industry. They know. Try getting an outside hashgachah in an area that is already someone's turf .... Most are just businesses with a touch of religion. Just enough to use it to bully us into following their program. Do you remember when Drakes [a widely marketed brand of snack cakes] was under Rabbi Ralbag and it was treif [non-kosher] according to some of these guys[?] Then the establishment organization got the account, now it's kosher. Do you think they went out [and] kashered the whole plant [and] changed all the ingredients?

497. See, e.g. Citing Serious Kashrus Violations Volover Rov Removes Hechsher from Franchise of Bakery, Vos Iz NElAs, (May 25, 2009), http://www.vosizneias.com/32336/2009/05/ 25/borough-park-ny-volover-rav-removes-hechsher-on-some-korns-brand-bake-products-ok-re affirms-its-kosher/.

498. See Matt Stevens, Kosher market targeted in USDA probe, class-action lawsuit, L.A. TIMEs, Apr. 2, 2013, http://articles.latimes.com/2013/apr/02/local/la-me-ln-kosher-market-usdalawsuit-20130402.

499. Id.

500. Id.

501. Id. The Doheny-Glatt matter was also linked to the Agriprocessors, Inc. scandal because Doheny Glatt Kosher Meat Market had been supplied by Agriprocessors, Inc. one of the many businesses owned by the Rubashkin family. See LA Kosher Meat Scnadal Deepens, FAiLedMesSIAH.COM, (Apr. 3, 2013), http://failedmessiah.typepad.com/failed_messiahcom/2013/04/la-ko sher-meat-scandal-deepens-345.html.

502. Aron Abadi, Ralbag meat, $Q \&$ A Board - View Post, Reply, Kashrut.org, (Jan. 24, 2005), http://kashrut.org/forum/viewpost.asp? mid=10338\&highlight=hashgachah. 
Rabbi Abadi is likewise dismissive of the case against Hebrew National. "As long as Rabbi Ralbag or any of his sons are involved there, you can be sure it is no problem. They never wanted him to succeed in the kashrut industry. This is an old war." 503

Indeed it is. Various Orthodox authorities have cast a negative eye on the Triangle K. Perhaps the clearest example is Coca-Cola, which was summarily banned when Triangle $K$ supervised it in the early 1990s - but immediately accepted as kosher the moment it was taken over by the OU even though there was no change in Coke's formula or processing. ${ }^{504}$ For his part, Rabbi Ralbag refrains from saying anything negative about other kosher authorities, except to refer to them obliquely with an old quote: "I think it's sometimes more important what comes out of someone's mouth than what goes into it." 505

An experienced and knowledgeable kosher supervisor estimated that "less than fifty percent of mashgichim today are fully qualified." "506 Ultimately, it becomes a matter of consumer trust, but trustworthiness can be very subjective. The OU and Star-K have had numerous disputes over specific products. Each, for example, has had a policy prohibiting caterers under its supervision from using meats certified by the other. Fans of kosher hot dogs might find this policy particularly egregious. Caterers under Star-K are currently forbidden to serve several brands of hot dogs that are under OU supervision. 507

\section{Conservative/Reform vs. Orthodox on Kashrus}

As glanced on above, the kosher business is subject to internecine squabbles, particularly the continuing struggle between the Orthodox and their Conservative and Reform brethren concerning which group's adherents buy the bulk of kosher food, and which body has the right to comment on its supervision.

Vos Iz Neías, a hasidic news blog that bills itself as "The Voice of the Orthodox Jewish Community," criticized the Conservative and Reform movements for deigning to voice their own opinions about kashrut:

503. Aron Abadi, Hebrew National, $Q \&$ A Board - View Post, Reply, Kashrut.org, (June 19, 2012), http://kashrut.org/forum/viewpost.asp? $\mathrm{mid}=10338$ \&highlight=hashgachah.

504. See LytTon, supra note 70 , at 87.

505. Interview with Rabbi Aryeh Ralbag, Head Kashruth Coordinator, Triangle K (July 2009).

506. Interview with Yaakov Blugrond, Former Chief Supervisor, Orthodox Union, in Sefat, Israel (July 2013).

507. Lasson, supra note 468. "Consumers calling the Star-K's kosher hotline are told that 'we don't have information' on those products. When asked if they can be used, the receptionist says, 'I guess not,' or 'We don't recommend them." Id. 
Only a small number of Conservative and virtually no Reform Jews observe kashrus, at least not the kashrus that is in accordance with Torah and halacha. So when the Rabbinical Assembly and United Synagogue of Conservative Judaism issued an advisory to its members and constituents asking them to evaluate whether it is appropriate to consume Rubashkin products, who exactly were they talking to? 508

To which FailedMessiah.com, which often criticizes Orthodoxy from the perspective of an informed halachic observer, offered a response that underscores the mercantile underpinnings of modern kosher supervision:

This bluster is not about kosher - it is about money ... . [N]onOrthodox Jews buy most of the kosher meat in America . . . . [I]f you factor in the Modern Orthodox, haredim may account for 20 percent of kosher meat sales - at best. Yet haredim control how that meat is produced. If Modern Orthodoxy ever decided to go it on its own, or if the Conservative Movement and the left wing of MO joined forces in their own hechsher, haredim ... will quickly lose their industry dominance. ${ }^{509}$

\section{Business Ethics for People and Animals}

The Agriprocessors Inc. controversy provides an illustration of the highly competitive business nature of the kosher food industry. In May of 2008, federal officers descended on the Agriprocessors Inc. kosher slaughterhouse and meat packing plant in Postville, Iowa. They made more than 300 arrests, "most of them illegal immigrants from Guatemala and Mexico, on charges of use of stolen social security numbers and similar offenses." The Agriprocessors management was charged with violating child labor laws and other abusive practices, such as imposing 17-hour workdays on employees. "[A]n animal rights group claimed that cows there were inhumanely slaughtered."

"Reports of abusive or illegal behavior at Agriprocessors over the last few years have opened the kosher food industry and the wider Orthodox community to criticism from outsiders, including animals rights advocates and progressive Jewish groups." One of the progres-

508. See Conservative and Reform Movements Despicable, Ludicrous, Spoofs On Kashrus, Vos Iz NelAS, (JuNE 11, 2008), http://www.vosizneias.com/16916/2008/06/11/new-york-conserva tive-and-reform-movements-despicable-ludicrous-spoofs-on-kashrus/. The Rubashkin products refer to those from a company allegedly engaged in animal cruelty. See Duara, supra note 538.

509. "Conservative and Reform Movements Despicable, Ludicrous, Spoofs on Kashrus", FAILEDMEssiah.com (June 11, 2008), http://failedmessiah.typepad.com/failed_messiahcom/ 2008/06/conservative-an.html. Moreover FailedMessiah.com goes on, "What these 'saintly" haredi rabbis did on arrival from Europe was to ignore both the customs of Orthodox America and the halakhic decisions of American rabbis and demand standards of kashrut well in excess of halakha." Id. 
sive groups is the Orthodox Social Justice Movement (or "Uri L'Tzedek"), which established an "Ethical Seal" (or "Tav HaYosher") program to insure fair treatment of employees in the kosher food industry. Restaurants that receive a Tav HaYosher approval notice, which are designed to be posted as conspicuously as standard kashrut certificates, have been judged to meet state guidelines of fair pay and safe work environments.

Both the Modern Orthodox and Conservative movements also responded to the Agriprocessors controversy, the former establishing a task force "to develop business and ethical guidelines for the kosher food industry", the latter creating a "Magen Tzedek" seal of certification for compliant businesses.

Recently animals have also been the focal point of ethical treatment. In May of 2014, an Orthodox rabbi came forward in a Wall Street Journal op-ed to drive home the point that kashrut in its purest form should be spiritually elevating:

For generations, kosher slaughter was a more intimate and thoughtful religious act. A century ago, the slaughtering was often handled by Jews in their own backyards. Meat consumption was much lower and was reserved for meals on the Sabbath and holidays. My grandfather was a butcher, and I can recall his singular passion for his service and his love for animals. But over time kosher slaughter has followed the trend of the non-kosher meat industry, toward large-scale industrial production, with animals leading bleak existences before the final trauma of slaughter. ${ }^{510}$

The rabbi wrote that the more he learned about the "reality of industrial kosher slaughter," the more he realized "how far current practices of animal treatment and slaughter differed from the traditional ethical values." $511 \mathrm{He}$ found that "animals sent to kosher slaughterhouses were raised [under the same harsh conditions] as those sent to non-kosher slaughter." 512 Feeling that he "simply couldn't spiritually separate what he was eating from the knowledge of its origin," he became a vegetarian. ${ }^{513}$ "The fact that the modern reality of industrial food production extends into kosher facilitieswhich are supposed to be held to the highest ethical standards of

510. Shmuly Yanklowitz, Why This Rabbi Is Swearing Off Kosher Meat, Editorial Opinion, WSJ (May 29, 2014), http:/www.wsj.com/articles/shmuly-yanklowitz-why-this-rabbi-is-swearingoff-kosher-meat-1401404939?tesla=Y\&\%24HeadlineQueryString\%24.

511. Id.

512. Id.

513. Id. 
treatment-brings me embarrassment and shame as an Orthodox rabbi and as a Jew." 514

According to U.S. Department of Agriculture regulations, "calves that are too sick or injured to raise to their feet should be immediately euthanized [instead of] being brought to slaughter." 515 Some slaughterhouses, including kosher facilities, have sought to circumvent the regulation by shocking and kicking downed calves, lifting them by their tails and ears, or dragging them by chains to the slaughtering chamber. ${ }^{516}$ As a result, the Humane Society of the United States "filed a legal complaint and forced the USDA to investigate this cruelty, after taking a video at a slaughterhouse [in Shrewsbury, New Jersey]" - one that does shechita as well as non-kosher butchering. ${ }^{517}$ Operations at the plant were suspended..$^{518}$

\section{What's in a Domain Name?}

The modern world of instant access to information through cyberspace has had an effect on the highly competitive kosher business as well. In 2013, "a battle to control the word "kosher" in Internet addresses pitted [mainstream supervisory agencies] against [one] another" - all of them competing to use the most attractive online domain name. ${ }^{519}$ The Internet Corporation for Assigned Names and Numbers ("ICANN"), an international organization, met in the South African port city of Durban "to begin a major expansion of domain names," including "who can operate and license 'dot-kosher' as a suffix for Web addresses, the same way 'dot-com' and 'dot-net' are used." 520

In early, 2012, ICANN "began [to] accept[ ] applications for generic top-level domain names ("gTLDs"). ${ }^{521}$ At the time, the market for food labeled as kosher was estimated to be around $\$ 17$ billion. ${ }^{522}$ Even though obtaining a gTLD is an expensive process, costing "close to $\$ 200,000 "$ when all is said and done, "[e]xclusive control of the do-

514. Id.

515. Shmuly Yanklowitz, Why This Rabbi Is Swearing Off Kosher Meat, Editorial Opinion, WSJ (May 29, 2014), http://www.wsj.com/articles/shmuly-yanklowitz-why-this-rabbi-is-swearingoff-kosher-meat-1401404939?tesla=Y\&\%24HeadlineQueryString $\% 24$.

516. Id.

517. Id.

518. Id.

519. Ellen Rosen \& Hugo Miller, It's Rabbi Versus Rabbi in $\$ 17$ Billion Dot-Kosher Battle, BlOOMBERG, Jul. 17, 2013, http:/www.bloomberg.com/news/2013-07-18/it-s-rabbi-versus-rabbiin-17-billion-dot-kosher-battle.html [hereinafter Ellen Rosen].

520. Id.

521. Id.

522. See id. The figures were supplied by Packaged Facts, a market-research firm. Id. 
main name could give its owner [a significant amount of control] over the kosher supply chain." 523 A group calling itself Kosher Marketing Assets put in a bid for "dot-kosher," stating as its mission to promote kosher food certification in general, and OK Certification and its clients in particular." 524 OK Kosher projected it would have "more than 600 licensees by its third year of operation." 525

Five of Kosher Marketing Asset's ("KMA") major competitors quickly joined together in opposition claiming that the group sought to profit from a sacred tradition that should not be subjected to marketing so mundane and potentially misleading. ${ }^{526}$ "We think that if the term 'kosher,' which has important meaning in the Jewish religion, is commercialized, it will do a disservice to how religion in general should be treated and will harm the kosher public specifically," said the OU, the world's largest certification agency. ${ }^{527}$

OK Kosher responded that it "never intended to have sole control of the potential domain name," and that it was open to working with its major competitors: the Orthodox Union, STAR-K Kosher Certification Inc., Chicago Rabbinical Council Inc., the Kashruth Council of Canada, and Kosher Supervision Service Inc. ("KOF-K").528 The OK claimed that it had invited the other groups to join its oversight of the dot-kosher domain name, but that they were not interested. ${ }^{529}$

The OU's objection was ostensibly grounded on the idea that a profit-making organization like the OK should not be allowed to control an industry whose largest certifying agency was the non-profit OU. ${ }^{530}$ The Star-K's concern was that "a single agency would have the right to grant use of the kosher domain name."531 This was one of the few times that the competition among kosher certifiers hit the front pages. The dispute was a departure from past cooperation between the others and $\mathrm{OK}$, which often supervises individual chemicals and additives that may ultimately be combined into a final product that is certified by another agency. ${ }^{532}$

523. Id.

524. Ellen Rosen, supra note 556.

525. Id.

526. See id.

527. Id.

528. Id.

529. Rosen, supra note 556. "They don't have to become our partners, but they can't now complain we're trying to brazenly control dot-kosher." Id. (internal quotation marks omitted).

530. See id.

531. Id.

532. Id. 
A similar dispute involves supervision of Halal, the Muslim set of rules on food preparation and consumption. ${ }^{53}$ The United Arab Emirates, India and Saudi Arabia have all registered their opposition to any one entity owning dot-halal. .534 $^{53}$

In early 2014, ICANN ruled in favor of KMA, rejecting the challengers' primary argument that the domain would promote only one certifying agency:

$[\mathrm{H}]$ aving regard to the assurances given by the Applicant and to the current safeguards, ... there is today no serious ground for the accusation that the Application is designed to confer "monopoly status" on the Applicant over ".kosher" domain names and to permit the Applicant to engage in "exclusionary practices", or in any event that it could lead to such a result. Nor does it seem likely that upholding the Application would lead to a "usurpation" of kosher by the Applicant or, more simply, that the Objector will not be permitted to register a domain under "kosher." 535

\section{Summary AND CONClusion}

Prior to the Twentieth Century, adherence to the Biblical dietary laws presented relatively few quandaries for the observant consumer. Milk and meat were taken directly from the farm, and were separated in the kitchen and dining room. It was easy to determine what was kosher and what was not.

But with the advent of packaged food and the development of refrigeration and transportation systems, the rules became harder to apply. Supervision by individual rabbis and slaughterers eventually gave way to oversight by large certification agencies. The government stepped in to prevent fraudulent advertising and sales of kosher products, by way of legislation and litigation designed to protect consumers - eventually adopting narrowly tailored mandatory disclosure statutes, which require vendors who claim that a product is kosher to prove it. On the other hand, courts quickly recognized that they could not become involved in deciding the theological questions at the basis of kashrut without running afoul of the Constitution's separation of church and state.

The consumer should be able to determine upon his own initiative whether or not the product satisfies his particular religious requirements. That task is made considerably more difficult by the big-busi-

533. Id.

534. Rosen, supra note 556.

535. Union of Orthodox Jewish Congregations of America v. Kosher Mktg. Assets, LLC, Case No. EXP/424/ICANN/41, Reconsideration Request, II 90 (Jan. 14, 2014), https:/www.icann.org/ en/system/files/files/request-annex-uojca-30jan14-en.pdf (emphasis in original). 
66 DePaul Business \& Commercial law Journal [Vol. 13:1

ness culture of modern kosher certification, with its attendant competition for control of the market, clashing egos of supervisory rabbis, and, above all, profits. Both religious and statutory standards have limited value. Even with such guidelines in place, in the real world sacred cows have given way to holy wars - the resolution of which may have to wait for Messianic times. 